\title{
أثر أنموذج تراجيست في تحصيل مادة العلوم لتلامذة الصف الخامس الابتدائي
}

م.د آلاء فايق حبيب

جامعة سومر/كلية التربية الأساسية
أ.م.د رائد بايش الركابي

جامعة سومر/كلية التربية الأساسية لد الرية

\section{المستخلص :}

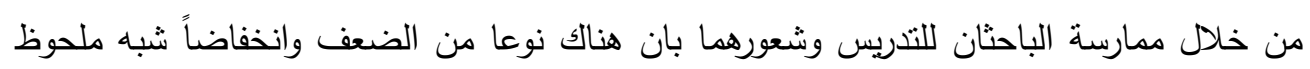

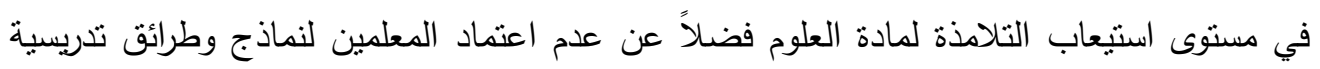
حديثة نتيجة عدم اطلاعهم عليها وإلمامهم بها وعدم تضمين خططهم الدراسية مهارات عقلية فباتوا

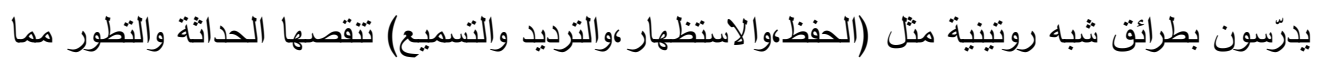

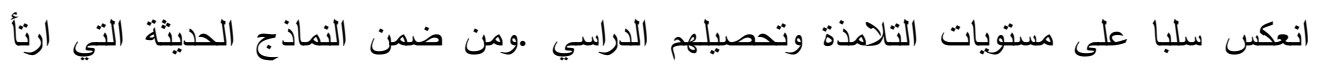

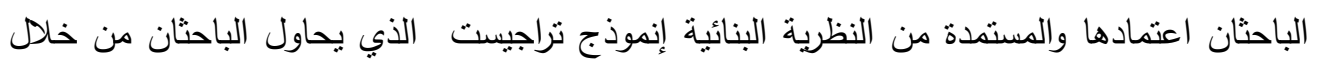

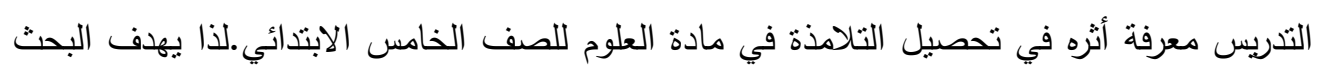
إلى معرفة أثر أنموذج ( Treagust ) في تحصيل مادة العلوم لتلادذة الصف الخامس الابتدائي

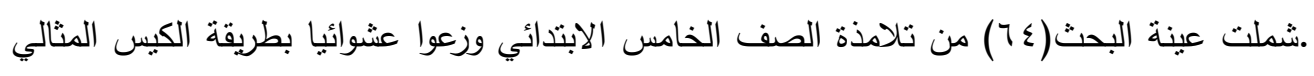

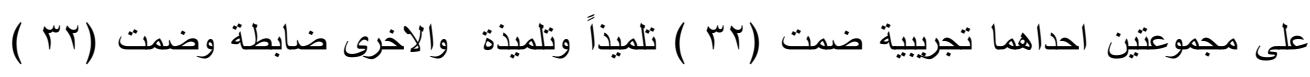

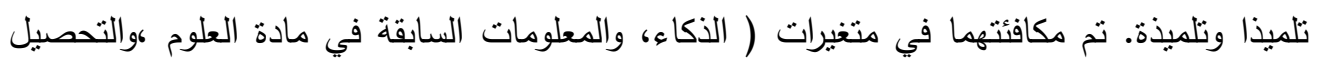

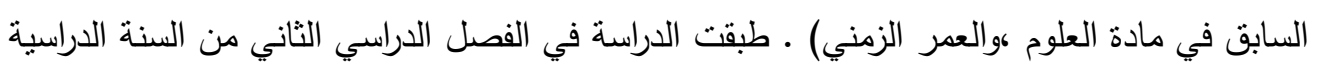

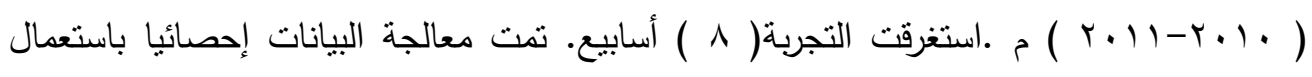

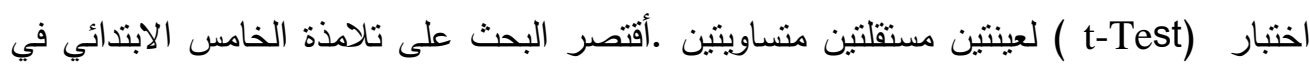

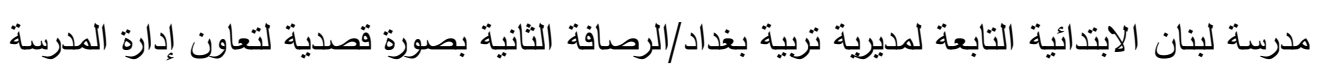

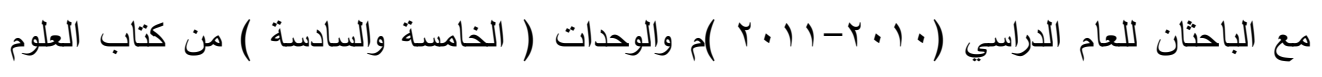

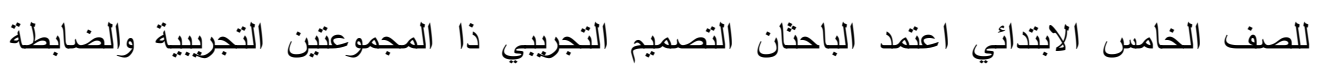

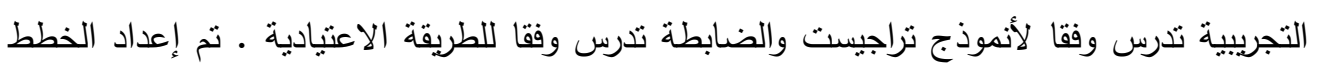
التدريسية للمجموعنين التجريبية والضابطة ، عرضت على مجموعة من الخبراء والمختصين للتأكد

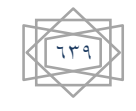


من سلامتها ودقتها،تم بناء اختبار تحصيلي بلغ عدد فقراته (Yr) فقرة من نوع الاختيار من متعدد

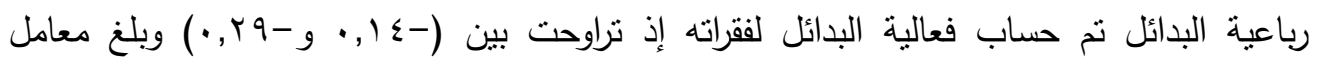

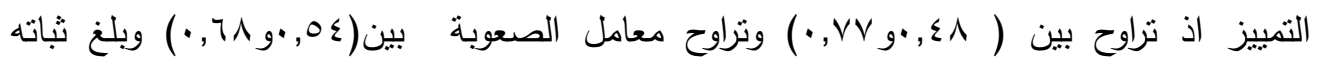
باستعمال طريقة التجزئة النصفية قبل التصحيح ( AV, · ) ) باستعمال معادلة سبيرمان براون بعد

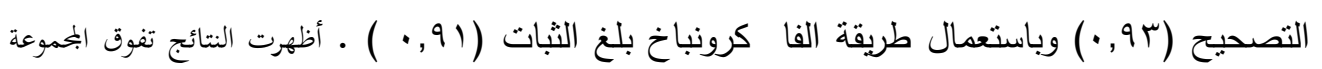

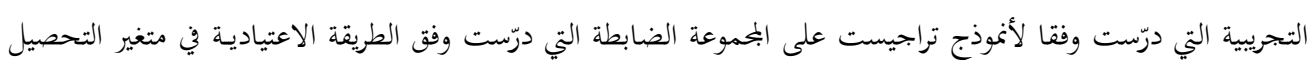

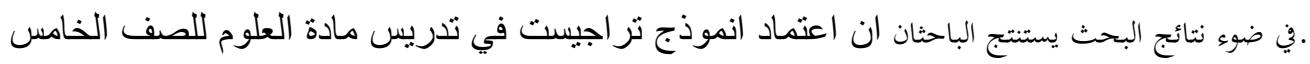
الابتدائي له اثر في رفع تحصيلهم في مادة العلوم .في ضوء نتائج البحث أوصى الباحثان باعتماد أنموذج تراجيست في تدريس مادة العلوم في المدارس الابتدائية والتتسيق بين وزارتي التعليم العالي

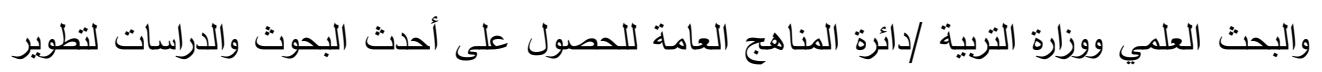
المواد الدراسية وإدخال أنموذج تراجيست ضمن مفردات مادة طرائق التدريس في كليات التربية ومعاهد إعداد المعلمين والمعلمات في برامج إعدادهم وتأهيلهم ،كما وضع الباحثان مجموعة من المقترحات في ضوء نتائج البحث التي تم التوصل إليها.

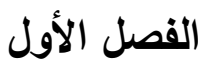

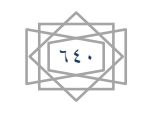


من خـلال خبرة الباحثان المتواضعة في التدريس واطلاعهما على درجات التلامذة للسنوات السـابقة فضلاً عن آراء بعض أولياء الأمور في اجتماعات مجالس أولياء الأمور والمعلومات التي توصلت دافت

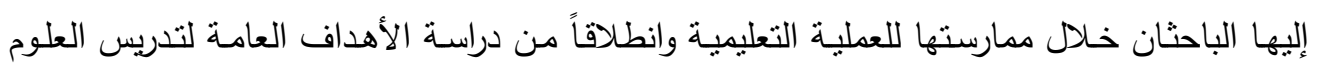
للمرحلة الابتدائية بشكل عام وتدريس مادة العلوم للصف الخامس الابتدائي بشكل خاص لاحظا إن هنـاك نوعاً مـن الضـف في تحصيل التلامذة الدراسـي بمادة العلوم وتدنياً ملموسـاً في مستوياتهم وخاصة في مادة العلوم في الصف الخامس الابتدائي ولكون المرحلة الابتدائية تتمثل باللبنة الأولى للمراحل التعليمية اللاحقة مما يترتب عليها من آثار سلبية قد تؤثز على النتيجة النهائية لتعلم التلاميذ ومنها تحصيلهم الدراسي وعلى تعليمه في السنوات اللاحقة ، وقد لمسا الباحثان أثناء استطلاع آراء معلمي مادة العلوم ،إن هناك ضعف في أدائهم قد يرجع سبب ذلك إلى استعمالهم أساليب نقليديـة في تدريس العلوم فضلا عن عدم اعتمادهم لطرائق حديثة ونماذج تدريسية متتوعة نتيجة عدم تدريبهم على هذه الطرائق التدريسية واطلاعهم عليها وإلمامهم بها فأصبحوا يعلمون بطريقة شبه روتينية مثل هل ( الحفظ والاستظهار والترديد والتسميع ) بعيدة عن الحداثة ومتطلبات العصر .

ومن خلال مراجعة الباحثنان للاراسات والبحوث التي تتاولت انخفاض تحصيل التلامذة في مادة العلوم وجدا أن أغلب الدراسات أظهرت أن أغلب الطرائق التدريسية المستعملة من قبل المعلمين في تدريس العلوم تعتمد على الثـرح والإلقاء والحفظ والاستظهار فضـلاً عن أن هذه الطرائق لا تثير

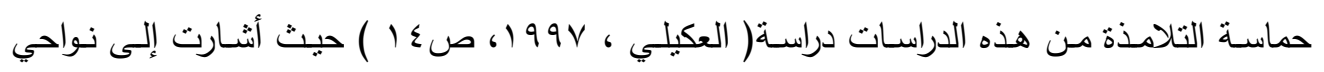
القصور في تعليم وتعلم العلوم ، إذ أظهرت نتائج هذه الدراسـة عن ان اكتساب المفاهيم العلمية في مادة العلوم العامـة للصف الخامس الابتدائي ان الطريقة الاعتيادية هي السائدة وان التلامذة تعودوا على السرد والإلقاء وإعطاء المعلومات الكثيرة غير المترابطة من قبل المعلمون مما يؤدي إلى نسيانها

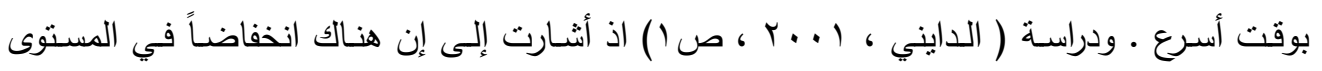
العلمي للتلامذة وضعف تحصيلهم بشكل عام وفي مادة العلوم بشكل خاص حيث ان هذا التدني سببه ضعف خبرة معلمي ومعلمات هذه المادة بالطرائق والأسـاليب التدريسية التي تثير اهتمام المتعلمين لممارسة العمليات العقلية وتعويدهم على أسلوب الحفظ لما يتلقونه من معلومات على وفق الأساليب

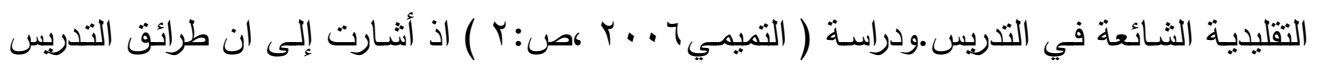

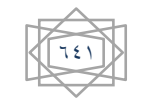


الاعتياديـة لـم تعد قـادرة على تأديـة دورهـا في توصـيل المـادة العلميـة بشـل يؤدي إلى تحصـيلها

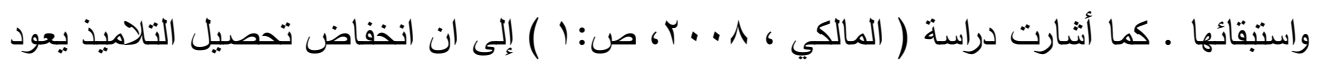

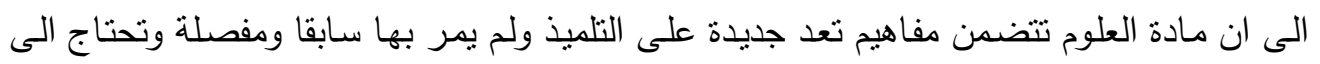
اعتماد طرائق تدريس تعتمد على استعمال المهارات العقلية من قبل التلاميذ، مما يساعد على توصيل

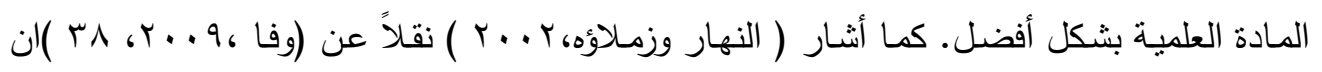
نتائج الدراسة التحليلية للاختبار العالمي Timms لعام 99 انتير الى تدني مستوى تلامذة المرحلة الأساسية في مادة العلوم. وقد يعزى ذلك الى استعمال أساليب تقليدية في طرائق التدريس مما يؤكد

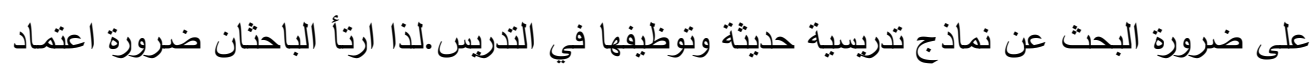
أحد نماذج تدريس مادة العلوم للمرحلة الابتدائية وهو أنموذج ( Treagust , 1993 ) اذ يعد أنموذجا مـن النمـاذج الواضـحة والمحدودة وهـو مستمد من إسـتراتيجية التشبيهات المنبتقـة من طرائق تعليم التفكير وخصوصسا التفكير الإبداعي المستمد من الفلسفة البنائية أي يبني المعلم المعرفة بنفسه. (

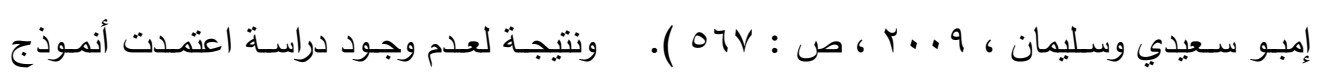
تراجيست وتعرّف أثره على التحصيل الدراسي ( على حد علم الباحثنان ) أرتا القيام بالدراسـة الحالية وقد راعا في اختيار هذا الأنموذج التدريسي قابلية اعتماده في تدريس مادة العلوم للمرحلة الابتدائية وخصوصسا" الصف الخامس الابتدائي كونه قد يؤدي الى زيادة كفاية العملية التعليمية وتحصيل وبناءً على ما سبق يمكن صياغة مشكلة البحث في السؤال الآتي: - ما أثز إنموذج ( Treagust ) في تحصبل مادة العلوم لتلامذة الصف الخامس الابتدائي؟

\section{ثانياً: أهمية البحث:}

ليس خافيـا على أحد التطور السـريع الحاصل في عالمنـا اليوم والقفزات التقدميـة الهائلـة في شتىى مجالات الحياة لاسيما مجال التربيـة والتعليم الذي يعد الأسـاس الذي ترتكز عليه الأمم التي تتشـ

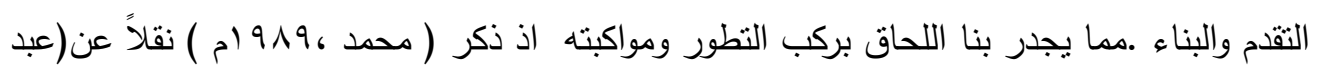

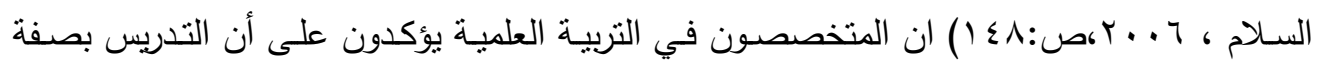
عامة وتدريس العلوم بصفة خاصة ليس مجرد نقل المعرفة الى التلامذة بل هو عملية تنساعدهم في بناء معارفهم وتطوير فهمهم عن العالم الطبيعي وتهنم بتكوينهم ونموهم ( عقلياً و وجدانياً و مهارياً )

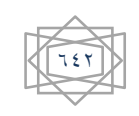




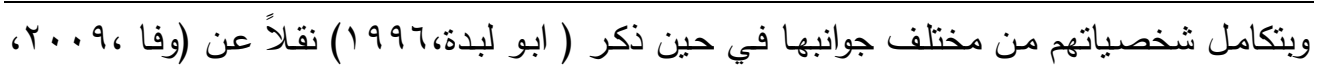

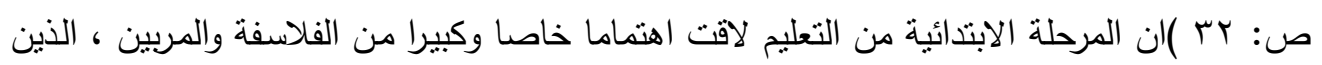

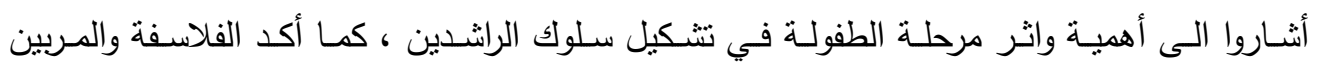
المحدثين ( في النصف الثاني من القرن العشرين ) وفي مقدمتهم (Jean piajeh and Bruner )

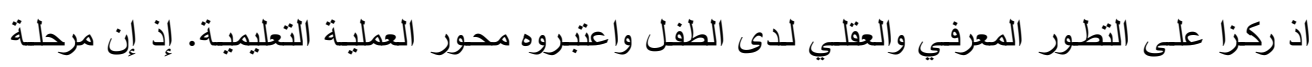

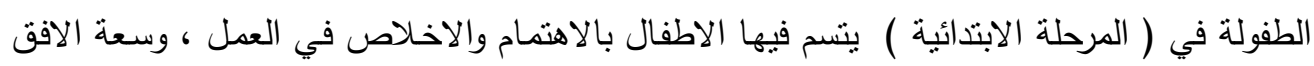

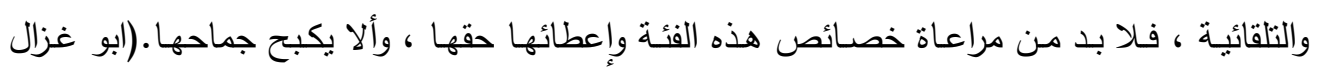

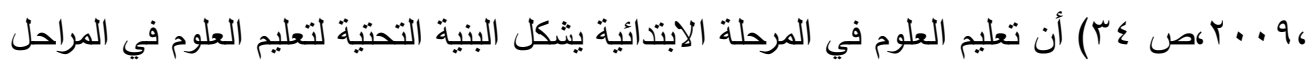

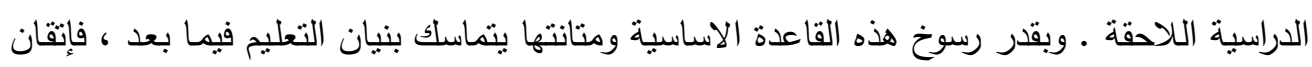
التلامذة للمفاهيم الاساسية في منهاج العلوم في هذه المرحلة يؤثر على إنقانهم وتقدمه في المراحل

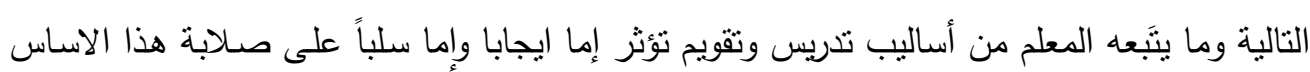

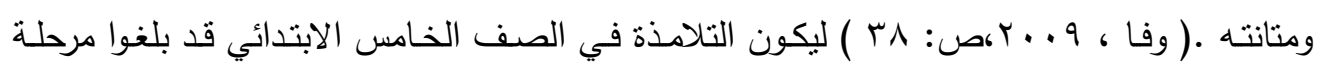

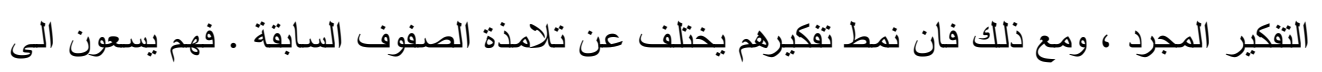

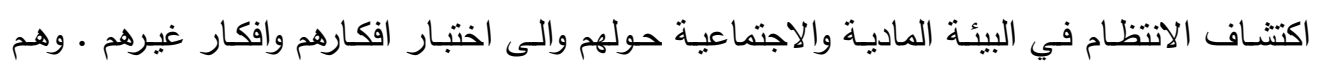

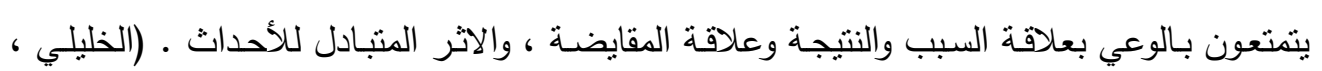

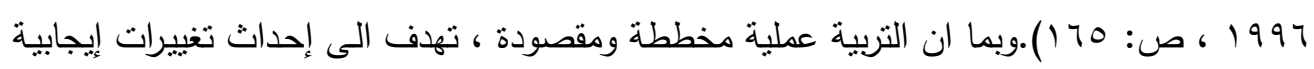

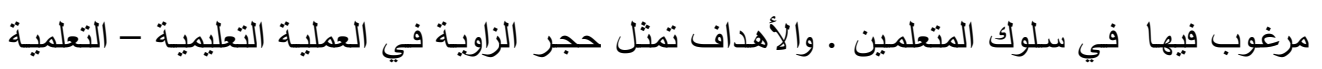

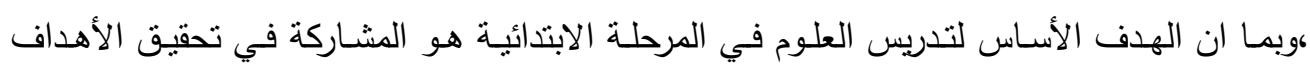

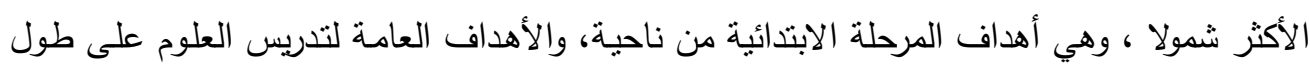

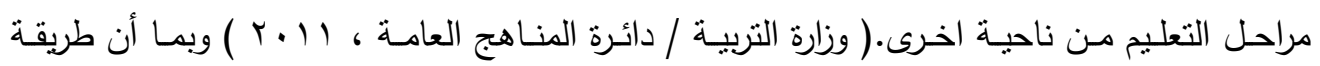

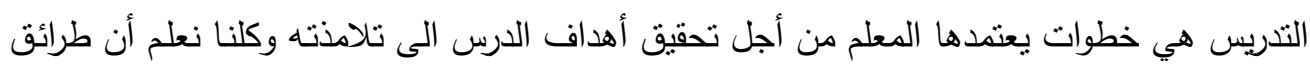

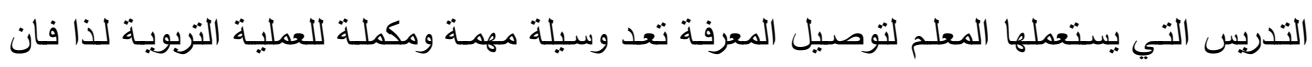

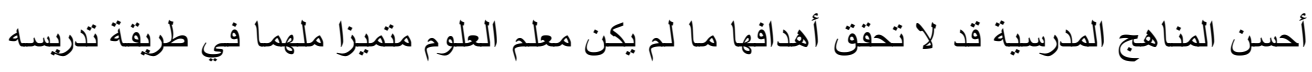

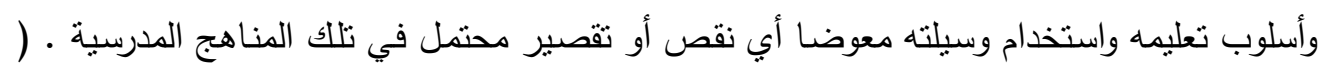

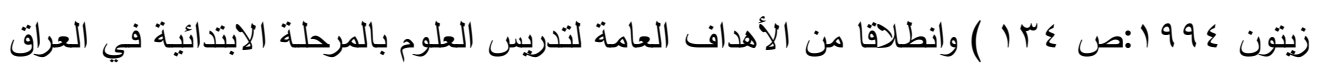

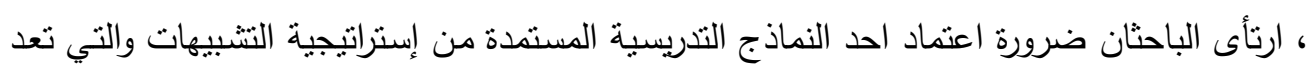


من الاستراتيجيات ذات العلاقة بمحتوى المواد الدراسية المرتكزة على أحدث النظريات في التدريس ألا وهي النظريـة البنائية .( قطامي ، 1991 ص: 11 1 ) ) وهناك العديد من الخطوات أو النماذج التي يمكن أن يتبعها المعلم في تدريس درس معين باستخدام التشبيهات على هذا الأسـاس ارتأ الباحثان

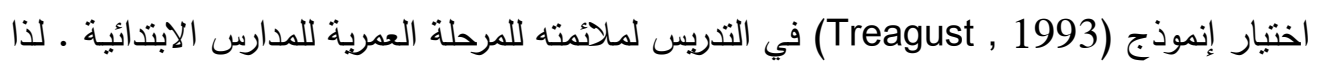

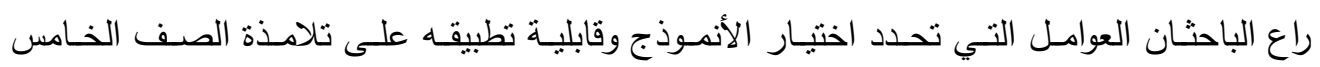
الابتدائي.

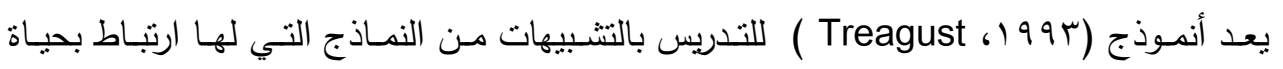
التلامذة فـالكثير مـن التلامـذة يستعملون التشبيهات في تقريـر ظواهر معينـه كمـا أن الأدب العربي والحياة العربية مليئة بالعديد من التشبيهات فكلنا نسمع عن تشبيه وجه المرأة بالبدر وتشبيه عيونها بعيون الغزال وتتبيه الدنيا بـالقنطرة للآخرة وغيرهـا من التشبيهات التي أثرت الأدب العربي واللغـة فئة العربيـة لذا فـن المهم جدا أن يستثر هذه الظـاهرة ويحاول توظيفها في الغرفـة الصفية لتوضيح

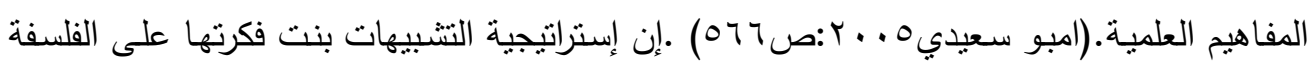
البنائية التي تعتمد على إن ما يحدد إدراك المتعلم بما في بيئته هو معلوماته وخبراته السابقة وتقوم

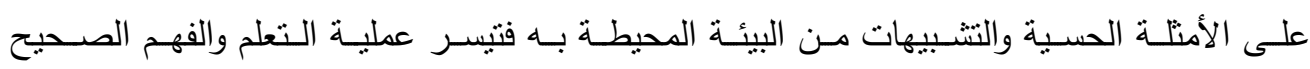

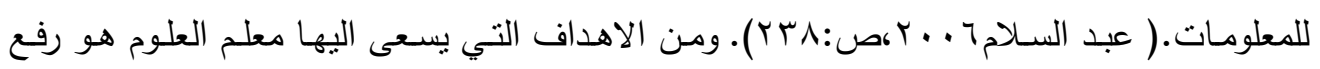
مستوى تلاميذه في كل المجالات،ولعل أهمها زيادة التحصيل المعرفي لتلامذته، وتحليل نتائجهر ،

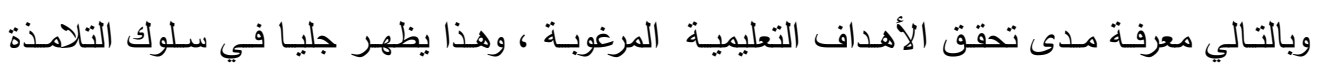
وأفكارهم بواسطة الاختبارات التحصيلية التي تعكس بصدق هذه الأهداف ، وتعد نتائج الاختبارات مقياسـا أو مؤشـرا عامـا لمدى نجاح المعلم في تحقيق أهداف عمله التدريسي والتربوي ( العفون

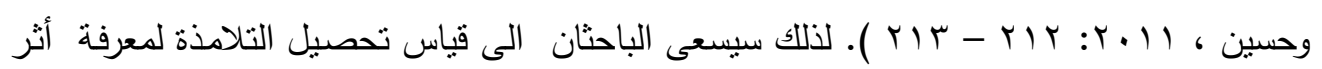
إنموذج نراجيست عليه .

لقد اتجه التربويون الى عقد المؤتمرات والندوات وإجراء البحوث والدراسات التي تمخضت عن نتائج وتوصيات كثيرة بهذا الثأن أكدت جميعها ضرورة تطوير المناهج وطرائق التدريس والنماذج التذريسية واعتماد أحدثها واهتم العراق في مجال تحسين مناهج العلوم وتطويرها ، وقد ورد في (

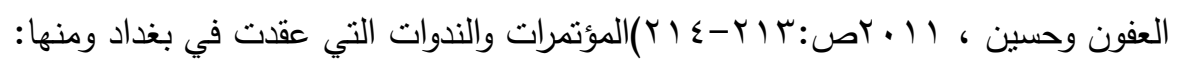




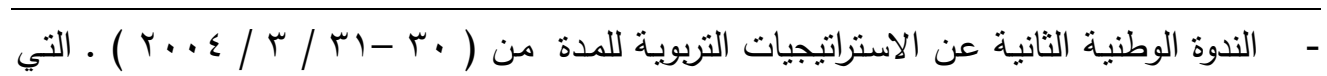
تتاولت الواقع التربوي في العراق جوانبه كافة ، وبحثت طرائق وتدريب المعلمين قبل الخدمة وفي اثثائها وكيفية الارتقاء بالواقع التعليمي بما ينسجم مع حضارة العراق وما وصلت اليه

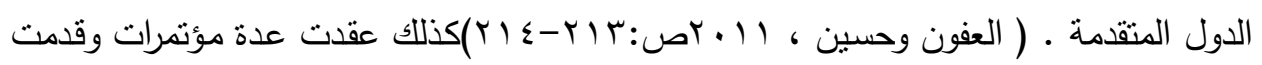
عدة مشاريع في الولايات المتحدة الامريكية أهمها المؤتمر المنعقد في جومنين ، تايلند ، مارس , 1990 حيث تم الخروج من هذا المؤتمر في الاعلان العالمي حول التربية للجميع بتوصيات تتعلـق بتوفير التعليم الاساسـي للجميـع ،والقضـاء على أميـة الكبـار ، وتحسين نوعيـة التعليم الاساس ، وايجاد طرق اكثر فعالية من حيث التكاليف من اجل تلبية احتياجات التعلم الاساسية

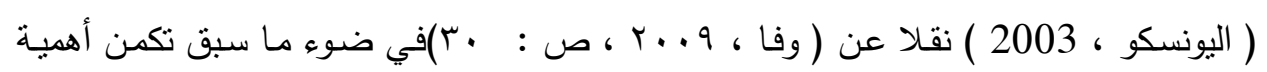
البحث في النقاط الآتية :

ا . أن تلامذة الصف الخامس الابتدائي هم الجهة التي قد تستفيد من هذه الدراسة .

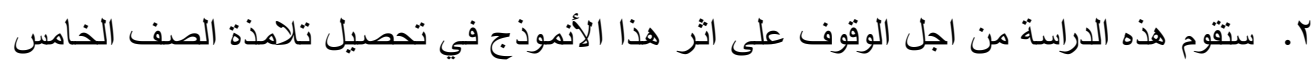
الابتدائي وفي مهاراتهم العقلية مقارنة بطرائق التدريس الاعتيادية .

\section{ثالثاً: هدف البحث : n}

يهدف البحث إلى معرفة : أثر أنموذج ( Treagust ) في تحصيل مادة العلوم لتلامذة الخامس الابتدائي.وذلك من خلال التحقق من الفرضية الصفرية الآتية :

-لا يوجد فرق ذو دلالة إحصائية عند مستوى دلالة (0 . ، ) بين متوسط درجات تحصبل تلامذة المجموعة التجريبية الذين يدرسون على وفق أنموذج ( Treagust ) ومنوسط درجات تحصيل تلامذة المجموعة الضـابطة الذين بدرسون على وفق الطريقة الاعتياديـة في الاختبار التحصيلي في مـادة العلوم.

رابعاً: حدود البحث:يتحدد البحث بالاتي : ا ـ الحد البشري :تلامذة الصف الخامس الابتدائي. 
العــــــد الثاني والعشرون

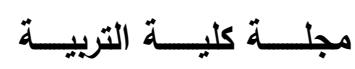

ץ ـ الحد المكاني:احدى المدارس الابتدائية التابعة للمديرية العامة لتربية بغداد/ الرصافة الثانية.

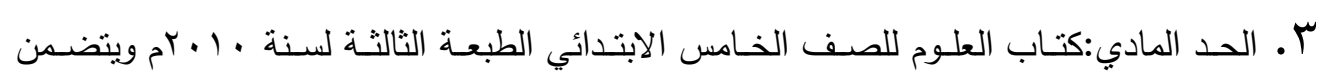
الوحدتان الخامسة: المغناطيس والكهرباء ، و السادسة: جسم الإنسان •

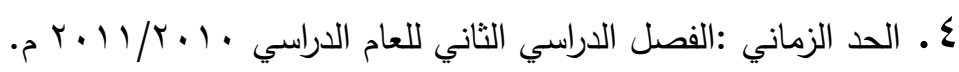
خامساً: تحديد المصطلحات:

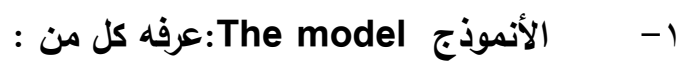

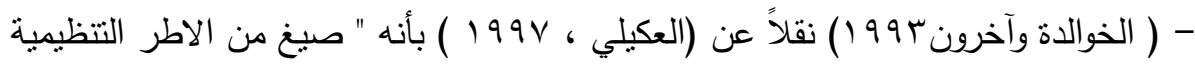
التي تقوم على وجهات نظر تفسيرية لتحقيق اهداف مهمة تتعلق بعملية التعليم والتدريس وتوجيه

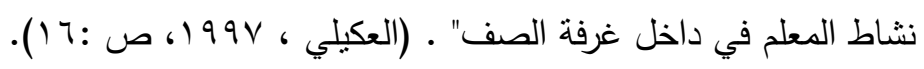

(Joyce and Weil ,2001) بانه " خطة نوجيهية تقترح اعتمادا على نظرية تعلم معينة مجموعة نتاجات وإجراءات مسبقة تسـل على المدرس عملية تخطيط نشاطاته التدريسية على

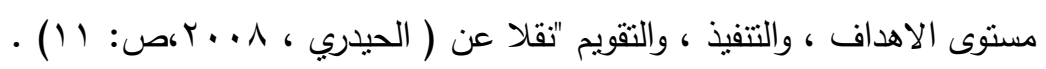
- التعريف النظري: يتبنى الباحثان تعريف (Joyce and Weil ,2001 ) - التعريف الإجرائي:هو خطة توجيهية تعتمد على النظرية البنائية وهي مجموعة خطوات تشهل

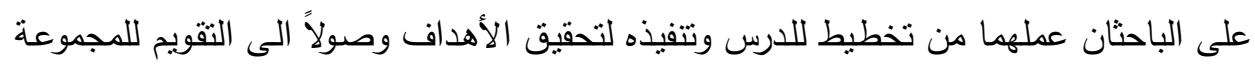
التجريبية لتلامذة الصف الخامس الابتدائي .

r- إنموذج تراجيست ( Treagust model ) :عرفه كل من:

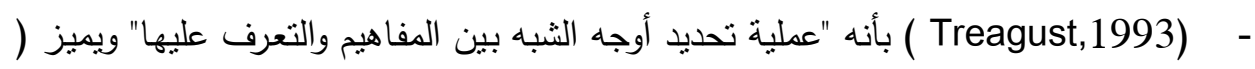

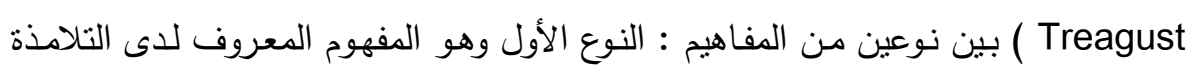
فيسمى بالمشبه (Analog) بينمـا النوع الأخر وهو غير المعروف الذي في الغالب هو

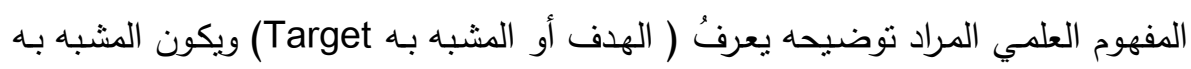

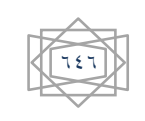


من حياة التلاهذة .حتى يمكنهم استيعاب عملية التشبيه كما أن كلا من الهدف ( المشبه )

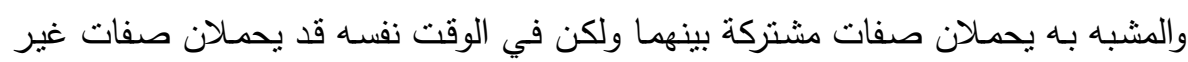

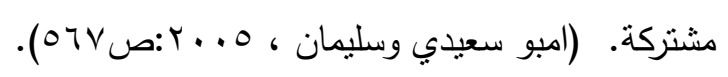

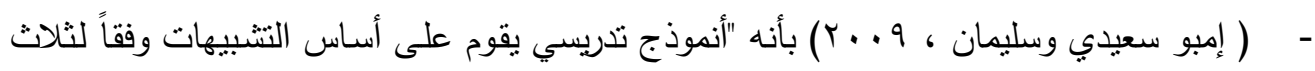

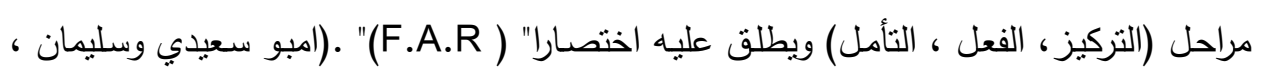

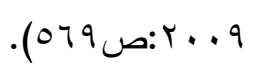

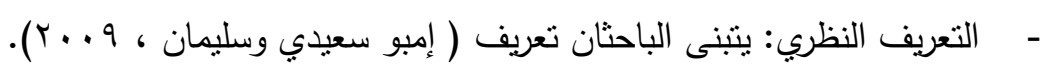
- التعريف الإجرائي : هو إنموذج تدريسي يزج المجموعة التجريبية من تلامذة الخامس الابتدائي

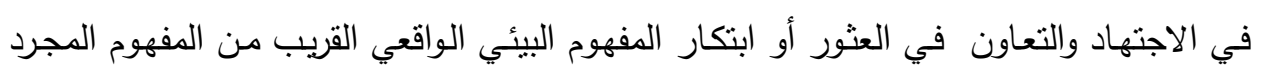

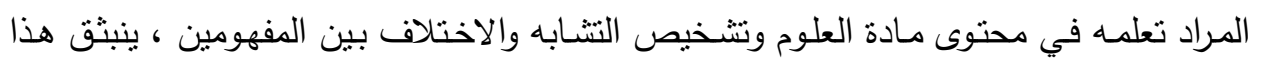

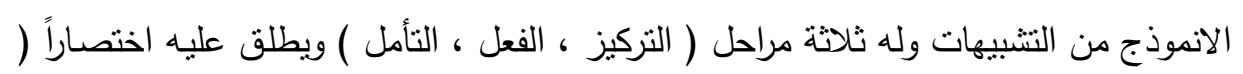
(F.A.R

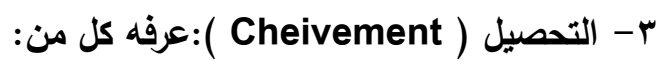

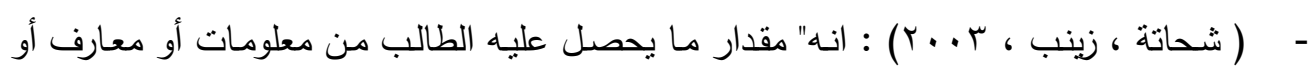

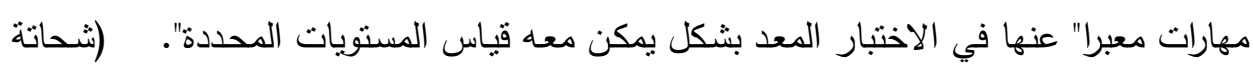

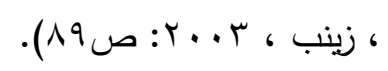

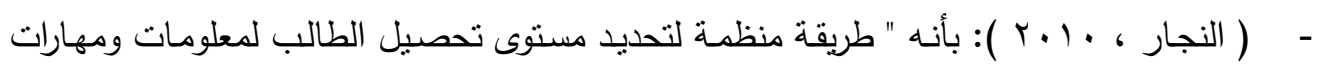

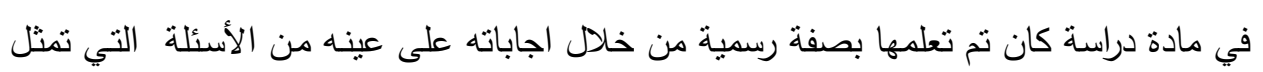

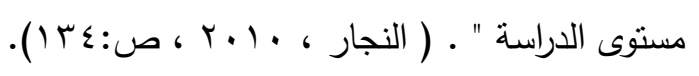

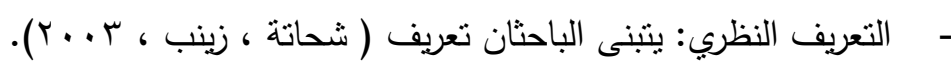

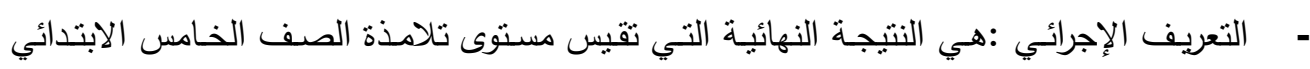

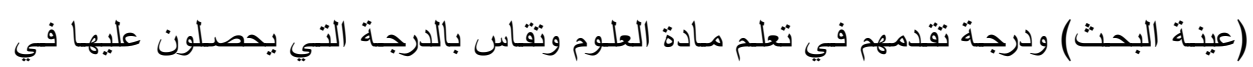

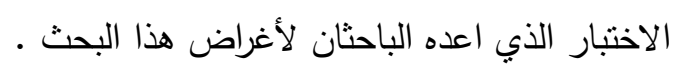

الفصل الثاني 
ينبثن انمـوذج ( Treagust ) مـن اسـتراتيجية النشبيهات المسـتمدة مـن الفلسفة البنائيـة لذا فـأن انموذج ( Treagust ) وليد للفلسفة البنائية التي تعد احدث فلسفة في تدريس العلوم. تعرّف هذه الفلسفة بأنها استراتيجية تدريس قائمسة على مبادى التعليم البنائي ، ويتتم من خلالها مسـاعدة

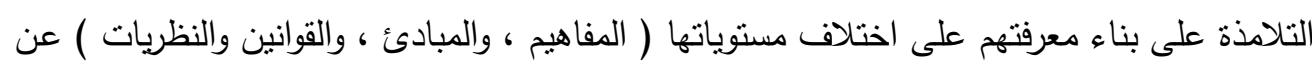
موضوع الدرس الجديد من خلال وضعهم في موقف ينضوي على (مشكلة او سؤال جديد )عليه يثير اهتمامهم ، ويطلب منهم الإجابة عنه ـ فيتضح ما لديهم من أفكار أولية ثم يوجهون إلى إجراء نشاط

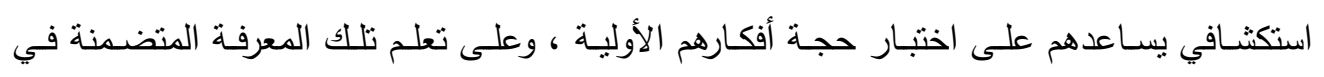

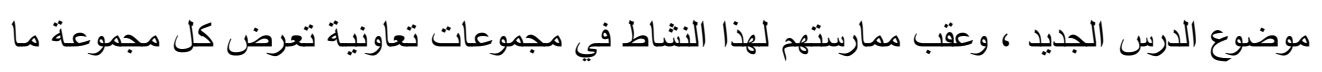

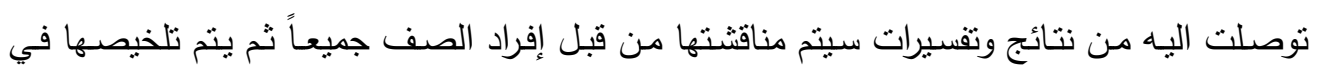

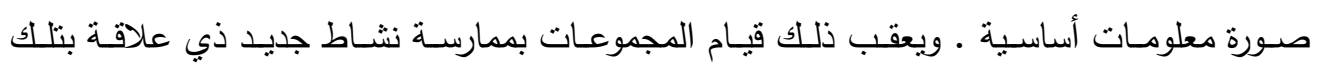

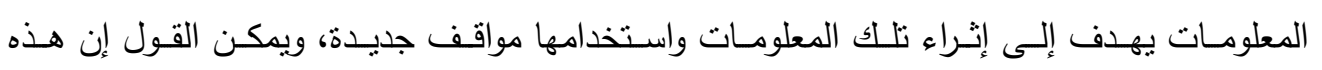
الإستراتيجية من استراتيجيات التدريس المتمركزة حول التلامذة أكثر من كونها متمركزة حول المعلم ف كما تساعد هذه الإستراتيجية التلامذة في تعلم المعارف الجديدة من خلال بنائها بأنفسهم ويكون هذا التعلم ذي معنى بالنسبة لهم ووثيـق الصـلة بحياتهم العمليـة ، كذلك تسـى إلى التأثنر على قدرة

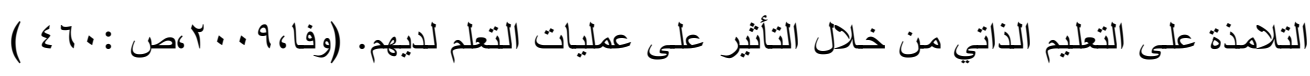
تقوم النظريـة البنائية على فلسفة مفادهـا انـه اذا كان النبات يصنّع ( يبني ) غذائه بنفسـه ، أليس

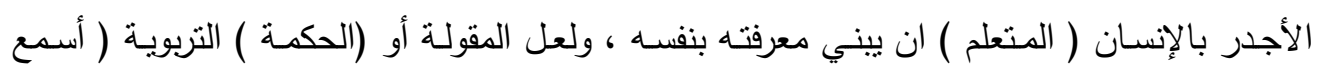
فأنسى ، أرى فأتذكر ، أعمل فافهم ) قد يكون الجزء الأخير منها يمثل النظرية البنائية ، اي التعليم

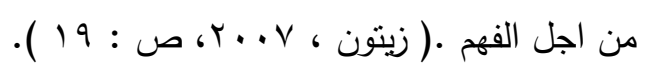


يرى (Reigeluth , 1989 ) نقلاً عن (ابراهيم ،9 ، . r) إن منظري تصـميم التعليم وفقا للفكر

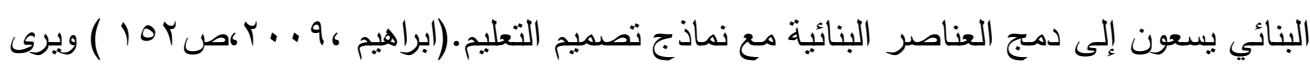

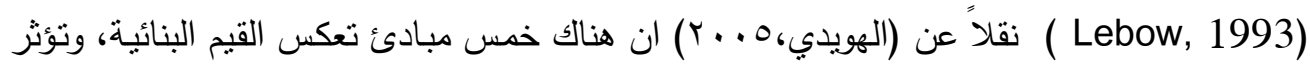
في تصميم التعليم ،وهذه المبادئ هي :

1- الاهتمام بالكيان الشخصي للمتعلم حيال ما يتعلمه . r- تقديم سياق التعلم الذي يدعم كلا من التتظيم الذاتي للمتعلم ومبادئه .

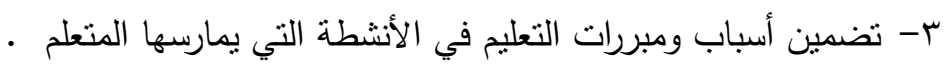
ع - تدعيم التعلم المنظم ذاتيا لدى المتعلم ومسؤوليته عن النمو العلمي ومتابعته الذاتية .

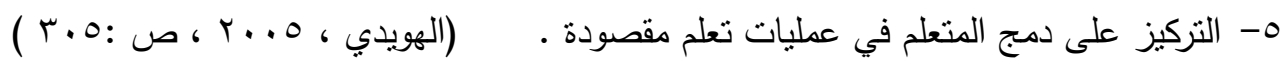

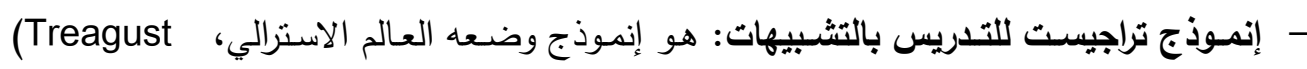

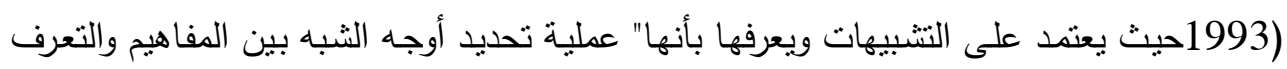
عليها" ويميز ( Treagust ) نوعين من المفاهيم النوع الأول هو المفهوم المعروف لدى التلامذة فيسمى بـ (المشبه بـهnalog) بينما النوع الأخر وهو غير معروف في الغالب وهو المفهوم العلمي المراد توضيحه يعرف بـ(الهدف أو المشبه Target ) ويكون المشبه به من حياة التلامذة حتى يمكنهم استيعاب عملية التشبيه كما أن كل من الهدف (المشبه) والمشبه بـه يحملان صفات مشتركه بينهما

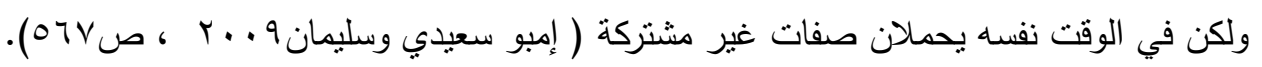
الأســاس النظري للتشـبيهات : إن أسـلوب كل من ( Stepich and Newby) هو استخدام التشبيهات عن طريق كيفية اكتساب الدماغ للمعلومات والمعرفة الجديدة وقد اشـارا بهذا الصدد الى الاتي "ان جميع المعلومات يتم خزنها في مذكرة أو فكر الانسان بشكل أو بصيغة تراكيب ( الادراك التفـاعلي ، التخطبط المرقع ، وحدات قيـاس أو مركبـات معرفيـة أو معلوماتيـة ، افتراضـات ، أطر فئر ومخطوطات ) إن اكتساب المعلومات أو المعرفة الجديدة تحدث من خلال اكتشافات فعالة أو تطوير العلاقـة التخطيطيـة بـين القطـع والاجـزاء الخاصــة بالمعلومـات والانـدماج في التراكيب التخطيطيـة الموجودة وقد أثناروا الى إن التشبيهات هي عملية ارتباط المعلومة الجديدة الى المعلومات المعروفة بلى والمألوفة". ( O,Brien,2002,p:70).

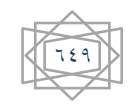


إن استعمال التشبيهات والتحسينات الخاصة بها ذات تأثير في حل أو تحويل الرموز من خلال

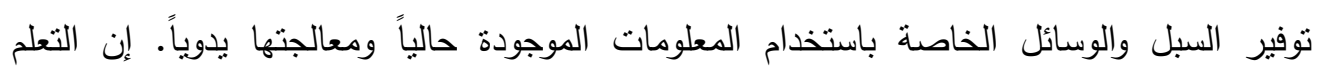

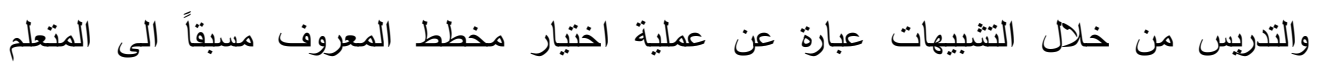

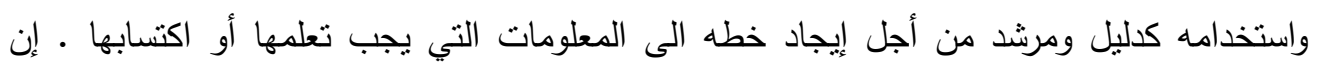
النتبيه لبس خطة أو مخطط للمعلومات الجديدة بل إنها وسيلة وسبيل لتكوين وايجاد مخطط أو أو خطة التهاد

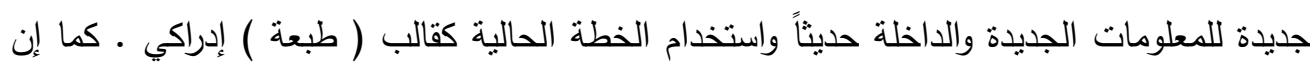

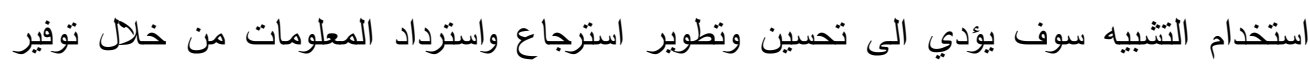

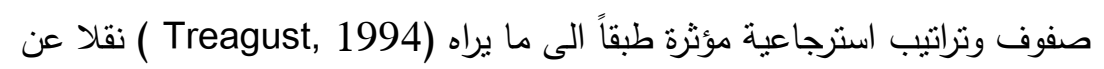

(O,Brien,2002,p: 70)

-فوائد التشبيهات :إن النتابه يقدم العون والمساعدة في عملية التصور أو التخيل في التعليم • إن

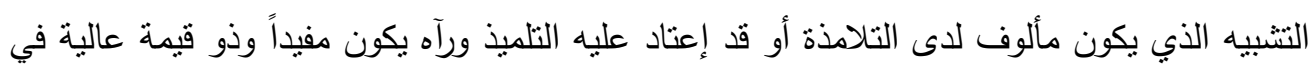

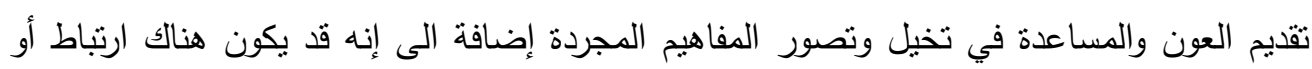

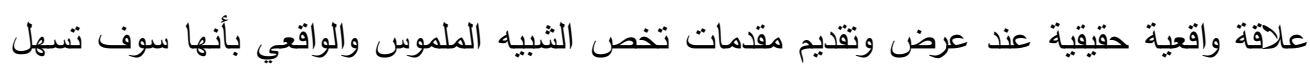

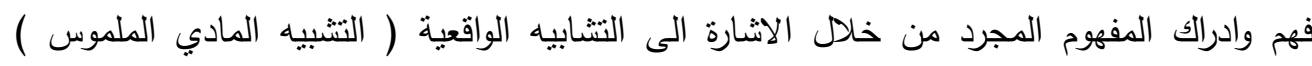

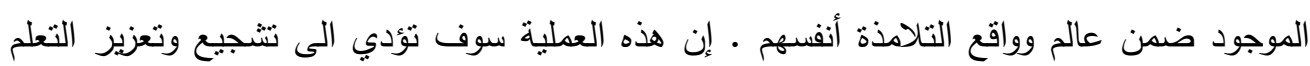

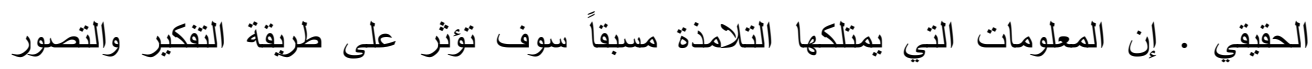

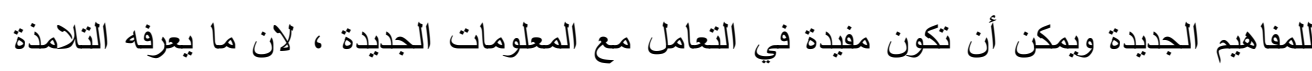

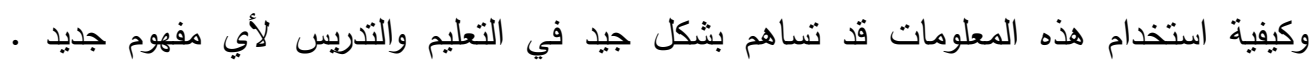

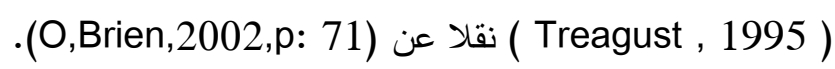

ويمكن تقسيم التشبيهات إلى نوعين ( لفظية ، مصورة ) فاللفظية يقصد بها استعمال الكلمات للتشبيه

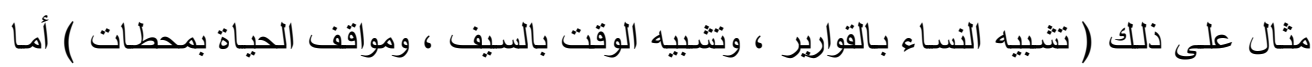

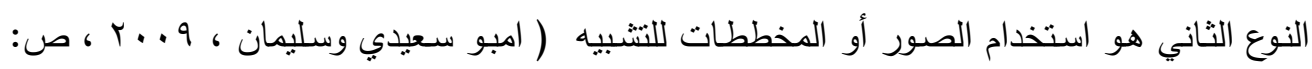

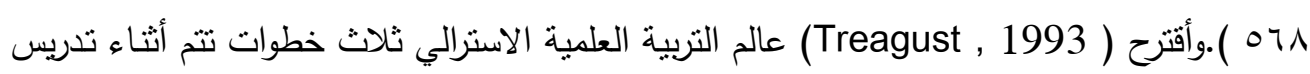

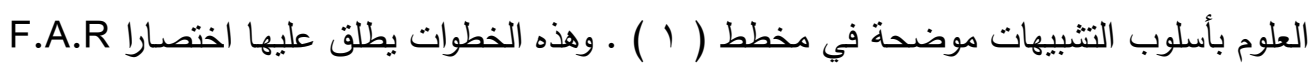

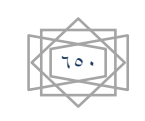




\begin{tabular}{|c|c|}
\hline \multirow[t]{2}{*}{ التوضيـح } & الخطوة \\
\hline & أولا": التركيز (focus) ويشمل: \\
\hline هل هو صعب ،ام مجرد ،ام غير مألوف؟ & \multirow{3}{*}{ 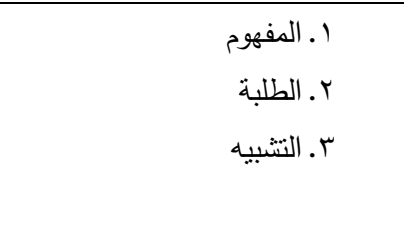 } \\
\hline ما المعلومات التي يعرفها الطلبة عن المفهوم؟ & \\
\hline \multirow[t]{2}{*}{ تذرسده الثيء الذي يعرفه الطلبة ومشـابه في بعض صفاته في المفهوم الذي } & \\
\hline & ثانيا": الفعل (Action) ) ويشمل: \\
\hline ما أوجه الثبه بين المفهوم العلمي والثيء المشبه به واكتبها على السبورة ؟ & \multirow{2}{*}{ 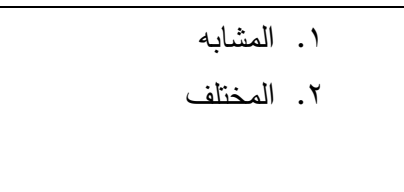 } \\
\hline مـا أوجـه الاختـلاف بين المفهوم العلمـي والثشيء المشـبه بـهـ واكتبهـا على & \\
\hline & ثالثا": التأمل(Reflection) ويشمل: \\
\hline هل التشبيه واضح ومفيد ولا يؤدي إلى غموض وتتشت؟؟ . & \multirow{2}{*}{ 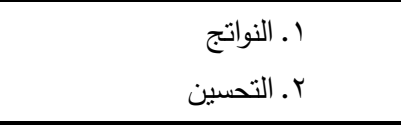 } \\
\hline التأكبد على ما سبق مع إعطاء أمتلة متتوعة للمفهوم. & \\
\hline
\end{tabular}

\section{مخطط) (1)}

\section{خطوات التدريس باستعمال إنموذج تراجيست}

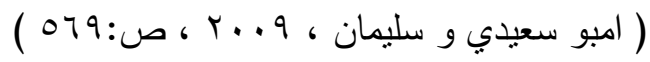

إن ( F.A.R - لتدريس النتبيهات في الصفوف .وقد تم 1994 - Treagust , 199 ) قدم أنموذج تطوير الأنموذج بالتعـاون مـع مدرسي الإعداديـة في استراليا وتضـمن العديد من الأمتلـة العملية

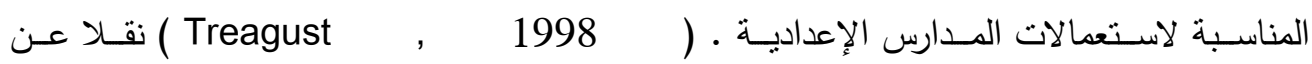
(O,Brien,2002,p:73) مفهومين ، ولا يتطلب ذللك تطابقا تاما مـع الثيء ، وما يتوقع من التلميذ ان يجريه في هذه الحالة مقارنة المشكلة الحقيقية أو ظروف المسالة بموقف آخر حتى يظهر منظورا أو فكرة جديدة ، ويتطلب

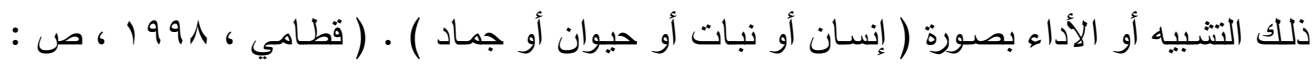

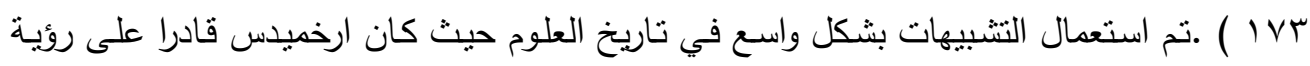
العلاقـة والربط بين المـاء المـزاح مـن المغطس ومـن ثم اجراء القياس بدقة لحجم التاج الذهبي إن التشبيهات قد استخدمت بهدف التعليم على تدريس أفكار جديدة وفي ذات الوقت تقديم الدعم والعون

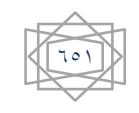


لحل المشـاكل والصعوبات من أجل ان يكون معنى للتعليم والتدريس ، إذ يجب اندماج المعلومات والمعرفة الحديثة مع المعرفة والمعلومات المتوفرة في الوقت الحاضر وهذه عملية معقدة تدخل فيها تفاعلات العمليات الاساسية الادراكيـة ومن ضمنها تكوين الصسورة او الفكرة الخياليـة وتتظيم ورسم التشبيهات ـ ومن خلال تفاعل هذه العمليات ، فان العقل يكون قادرا على بناء او تكوين العلاقة بين المفاهيم (Glynn , Duit and Thiele,1995) نقلا عن (O,Brien,2002,p:69) وان للتشبيه أربعة عناصر أساسية هي هي

- المشبه : ويقصد به في مجال التدريس نقطة المحتوى المطلوب ايضاحها.وعادة ما تكون صعبة Principle الفهم ، وقد تكون هذه النقطة مفهوما concept مثل مفهوم العين ، الذرة ) او مبدا

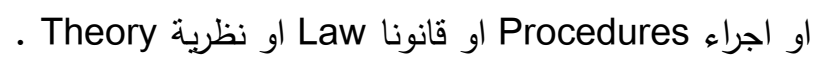
- المشـبه بـه : ( Analog ) ويقصد بـه الثـيء ( المـألوف )الذي يستخدم لتوضيح المشبه ـ اي يستخدم لإيضاح نقطة المحتوى محل التدريس للتلامذة ـ ومثال المشبه بـه الة التصوير الفوتوغرافي التي تستخدم لإيضاح المشبه ( العين مثنلا ) . - سمات التشـابه : Analogous Attributes ويقصد بها الخصائص المشتركة بين المشبه والمشبه به ( ولقد سبقت الاشارة لا مثلة لها في حالة العين والة التصوير ) . - سمات الاختلاف : Irrelevant Attributes: ويقصد بها أوجه الاختلاف أو الخصائص المغايرة بـين المشـبه والمشـبه بـه ( ولقـد سـبقت الإثـارة لأمثلـه لهـا فـي حالـة العـين وآلـة التصـوير ).

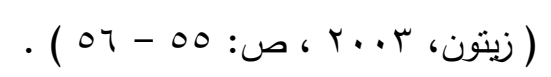
- مظاهر عملية التشبيه:إن عملية التشبيه لا تتحدد بقيود أو بضوابط بل التشبيه يشمل عدة جوانب ا- تشبيه في المظهر الخارجي كالحجم والثكل واللون مثل وجهها جميل كالبدر ، شعرها اسود كالليل. ץ- تشبيه في الوظيفة ، ويتجلى في كيفيـة العمل والأداء. مثل تشـابه عمل الحاسـوب التعليمي ووظيفة الدماغ البشري في تخزين المعلومات بحيث يحتاجها لمدخلان وعمليات ومخرجات. ب- التشبيه في التركيب والبناء يتجلى في الهيكل الداخلي مثل دخل الولد البيت ، أكلت البنت الطعام جملتان مفيدنان منشابهنان في البناء من فعل وفاعل ومفعول به. 
ع - التشبيه في الحو اس كالذوق و اللمس والشم و السمع و البصر مثل:عنب حلو كالعسل، رائحتها

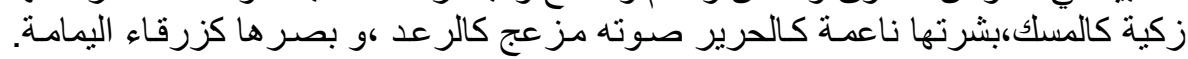

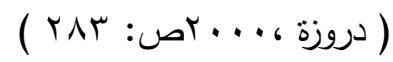

$$
\begin{aligned}
& \text { - التشبيهات في القران الكريم: }
\end{aligned}
$$

ومما يعزز أهمية التشبيهات (الاستعارة المجازية ) بانها ذات أصول إسلامية متجذرة في الرسالة السماوية المرسلة من قبل الخالق إلى الخلق كافة دونما تمييز بينهم عن طريق نبي الرحمة محمد)

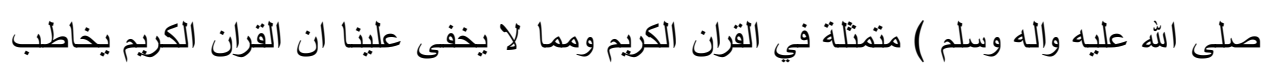
كل الناس وبكافة المستويات والأجناس فنلاحظ في الكثير من آياته وجود تشبيهات ( تعـابير مجازية ) لدورها البارز والمتميز في إيصال الفكرة وتحقيق الهدف المنشود منها بأبسط صورة كما

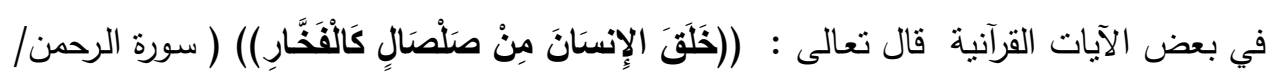

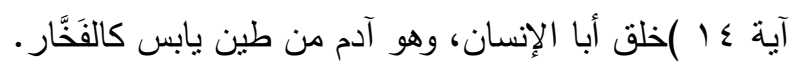

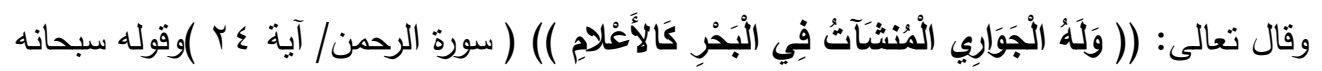
وتعالى السفن الضخمة التي تجري في البحر بمنافع الناس، رافعة قلاعها وأثرعتها كالجبال .وقال

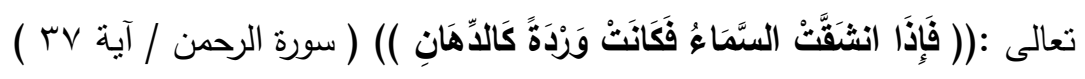

فإذا انشقت السماء وتفطرت يوم القيامـة، فكانت حمراء كلون الورد، وكالزيـت المغلي والرصساص

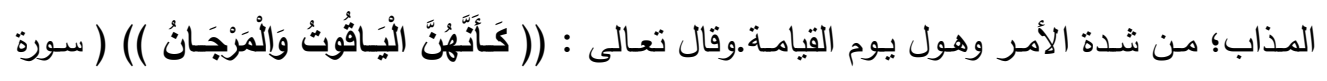
الرحمن/ آية هـ ) كأن هؤلاء الزوجاتِ من الحور الياقوتُ والمَزجانُ في صفائهن وجمالهن .

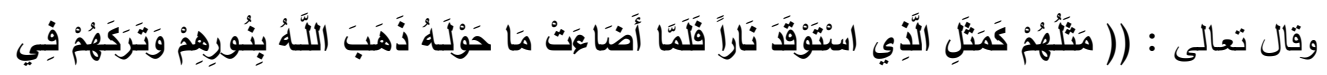

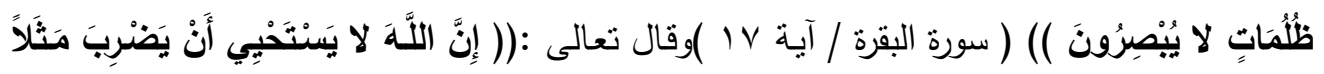

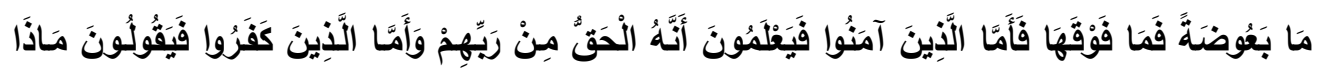

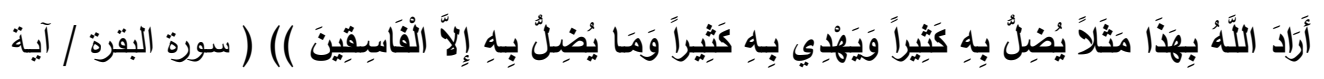

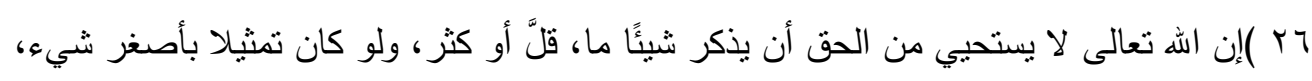

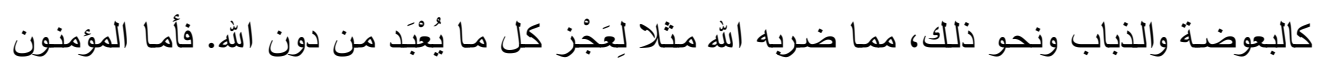
فيعلمون حكمة الله في التمثيل بالصغير والكبير من خلقه، وأما الكفار فَيَنْرون ويقولون: مـا مراد الله

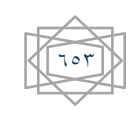


مِن ضَرْب المثل بهذه الحشرات الصغيرة؟ ويجيبهُ الله بأن المراد هو الاختبار، وتمييز المؤمن من الكافر ؛ لذلك يصرف الله بهذا المنل ناسًا كثيرين عن الحق لسخريتهم منه، وبوفق بـه غيرهم إلى مزيد

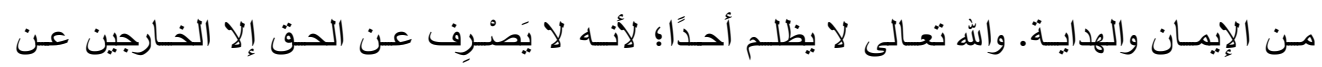

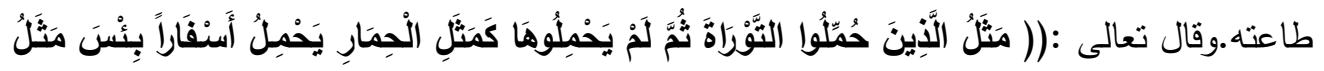

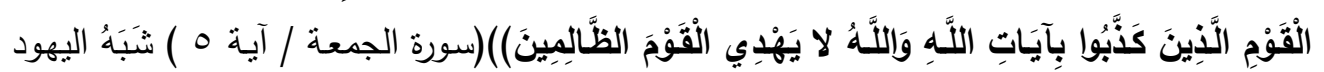

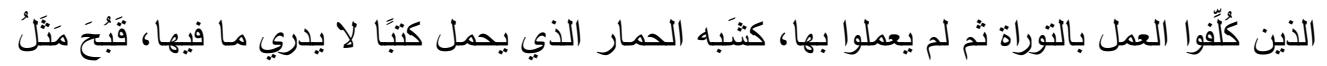
القوم الذين كذَّبوا بآيات اله، ولم ينتفعوا بها، واله لا يوفِّق القوم الظالمين الذين يتجاوزون حدوده،

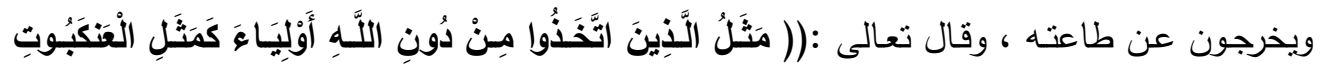

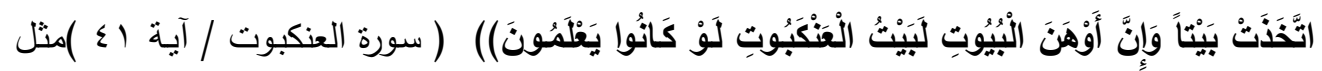
الذين جعلوا الأوتثان مسن دون الله أولياء يرجون نصـرها، كمثن العنكبوت التي عملت بيتًا لنفسها ليحفظها، فلم يُغن عنها شيبًا عند حاجتها إلبه، فكذلك هؤلاء المشركون لم يُغْن عنهم أولياؤهم الذين اتخذوهم من دون الله شينًا، وإن أضعف البيوت لَيبت العنكبوت، لو كانوا يعلمون ذلك ما اتخذوهم أولياء، فهم لا ينفعونهم ولا يضرونهم.

ثانياً : دراسات سابقة:نظراً لعدم وجود دراسات سابقة عن إنموذج تراجيست (على حد علم الباحثان) لذا سيتم تتاول الدراسات الأثية:

ا - دراســة (kleaner,1991 ) : هـدفت هذه الدراسـة الىى التعـرف على مـدى فعاليـة اعتمـاد استراتيجية التشبيهات على الفهم وقدرات التفكير الابداعي وقدرات الكتابة والتحصيل الاكاديمي

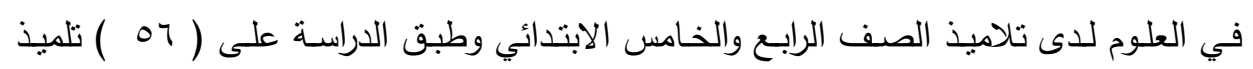
وتلميذة وقد كان اختيار عينة الدراسـة بطرقة قصدية وقسمت الى مجموعتين الاولى تجريبية حيث تم تدريسها باستعمال استراتيجية التشبيهات والمجموعة الثانيـة كانت ضـابطة حيث تم تدريسها بالطريقة المتبعة وطبق الباحث الاختبار التحصيلي واختبار توارنس للتفكير الابتكاري

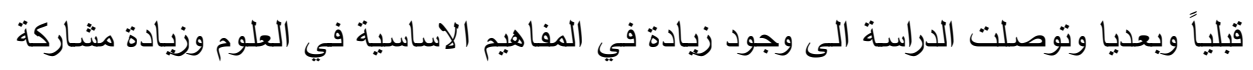

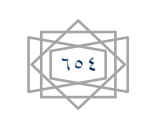


في اجراءات التدريس وزيادة القدرات الابتكارية ومهارات كتابية وذلك في المجموعة التجريبية

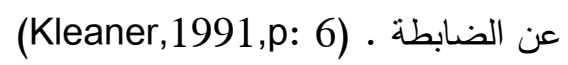

ץ- دراسـة (Treagust , 1992) : هدفت الدراسـة الـى معرفـة فعاليـة كل مـن التشبيهات فقط التح

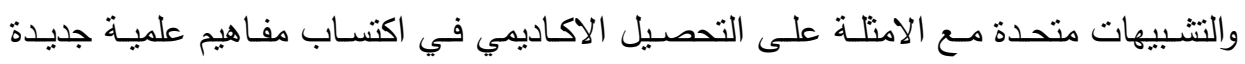

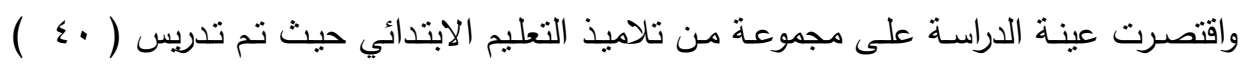

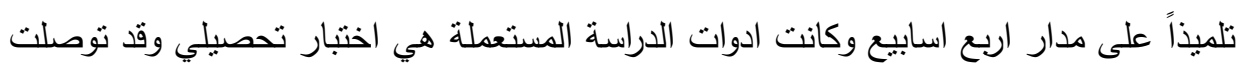

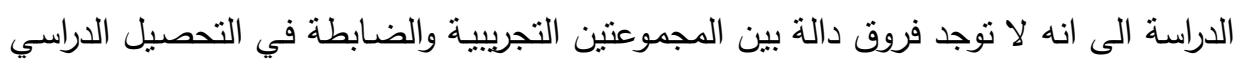

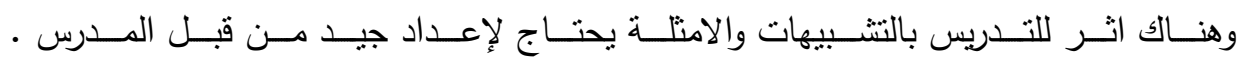
(Treagust, 1992,p: 4 )

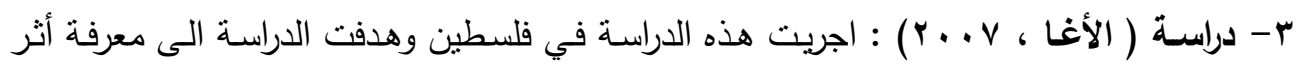

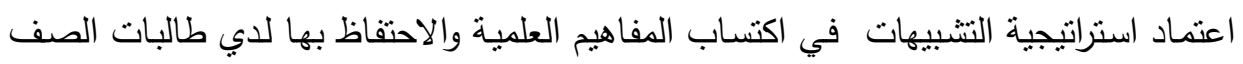

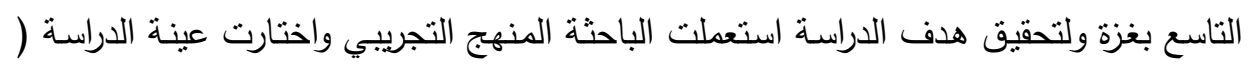

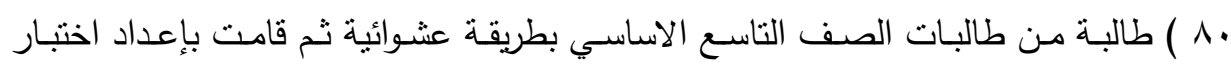
للمفاهيم العلمية ودليلا للمعلم ونشاط الطالب وبعد تطبيق الاختبار على المجموعتين الضابطة

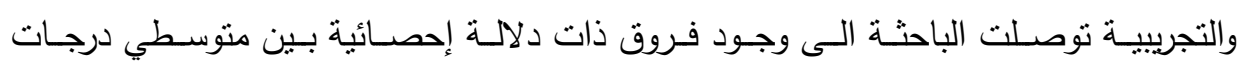

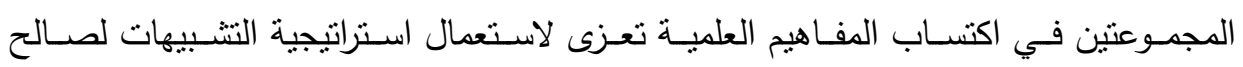

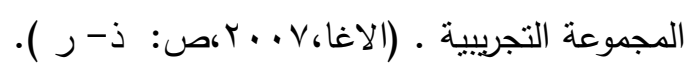

ثالثاً: دلالات ومؤشرات عن الاراسات السابقة :بعد الاطلاع على الدراسات السابقة استتنج الباحثة

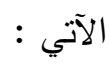
1- مكان إجراءها : بعض الدراسات السابقة أجريت في فلسطين مثل دراسة( الاغا، V . . r) ،امـا هذه الدراسة فقد أجريت في العراق • بعض الدرات العات r- الأهداف :تباينت الدراسات السابقة في أهدافها فالدراسات التي اختصت بالمتشابهات استهدفت

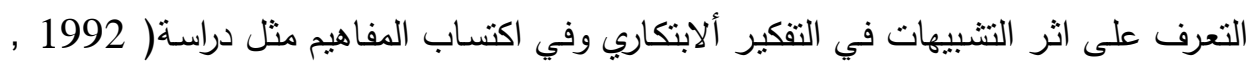

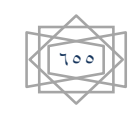




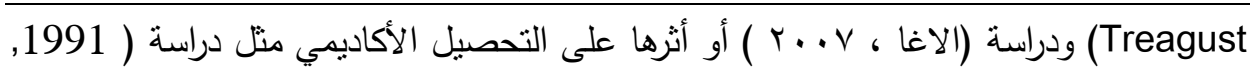
Kliener انموذج نراجيست في تحصيل مادة العلوم والمهارات العقلية لتلادذة الصف الخامس الابتدائي. r- حجم العينة : تباينت الدراسات السابقة فيما بينها من حيث حجم العينة ' فترارح حجم العينة من

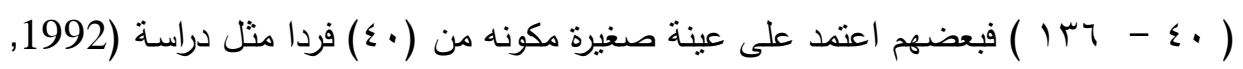
Treagust العينة كبيرا لصعوبة السيطرة على المتغيرات .

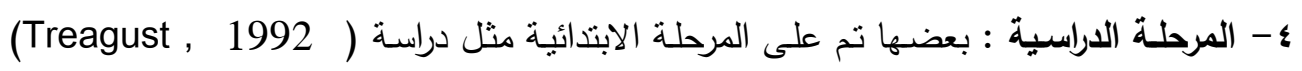

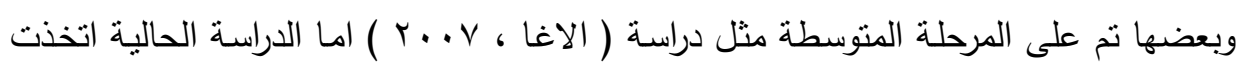
تلامذة الصف الخامس الابتدائي .

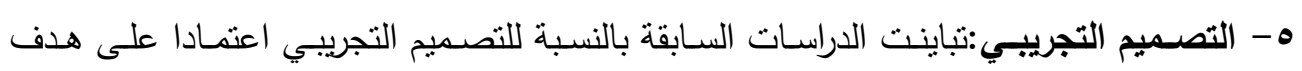

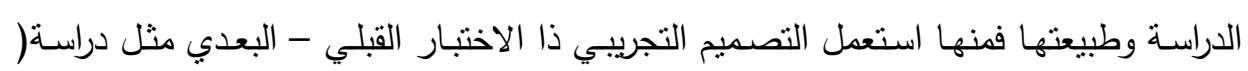

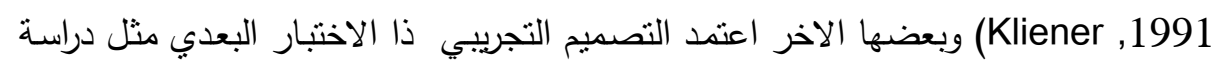

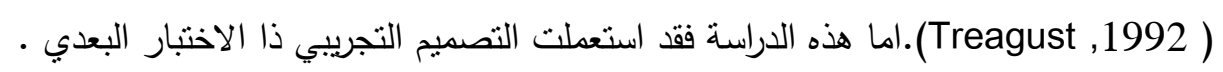
צ- مدة التجرية : تباينت الدراسات السابقة في الددة التي استغرقتها التجربة (• كيوم ) و (r اليوم

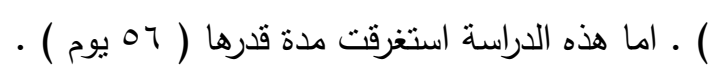

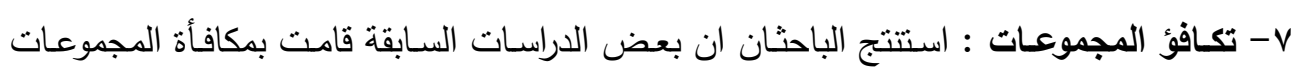

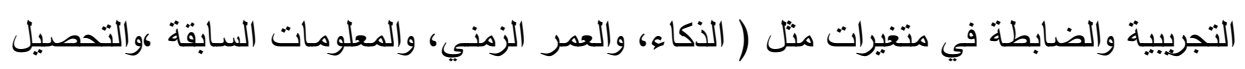

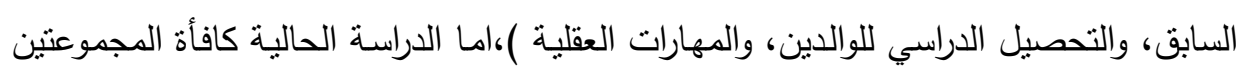

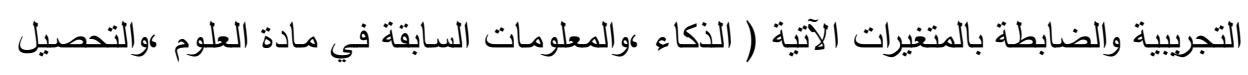
السابق في مادة العلوم ،والعمر الزمني ). 
^- أدوات الدراســة : نباينت الدراسـات السـابقة في ادوات الدراسـة تبعـا لأهدافها فبعضهـا اكتفت بالاختبار التحصيلي منل دراسة(Treagust , 1992) والبعض الاخر التبات النبار تحصيلي واختبار

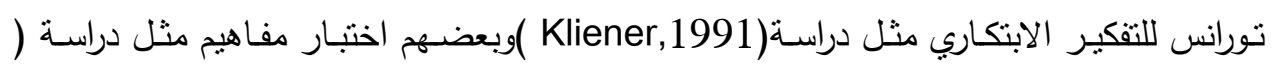

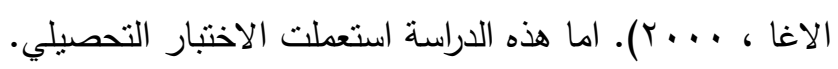

9- نتائج البحث : استتتج الباحثنان ان نتائج الدراسات السابقة التي درست وفقا للتشبيهات تفوقت فيها

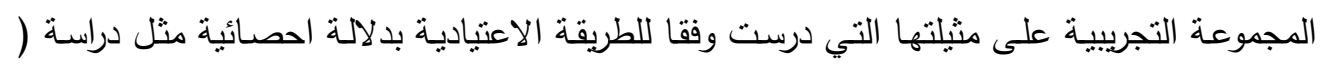

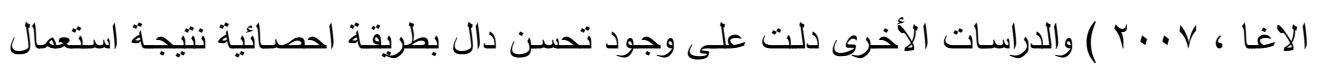

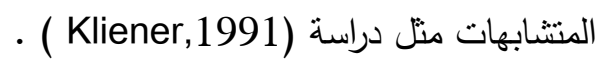

\section{أفاد الباحثان من الدراسات السابقة الآتي:}

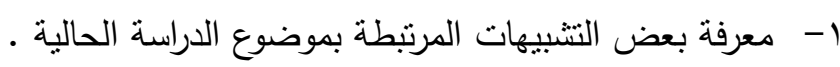
r- بناء الإطار النظري وكذلك بناء الاختبار ألتحصيلي. r- نتائج بعض الدراسات المرتبطة بموضوع الدراسة الحالية وتفسيرها .وسيتم مقارنتها مـع نتائج هذه الدراسة التي سيتم توضيحها في الفصل الرابع •

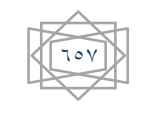




\section{العــــــدد الثاني والعشرون}

\section{الفصل الثالث}

إجراءات البحث:يتضمن هذا الفصل عرضا للإجراءات المتبعة في البحث وكالاتي:

model ) أولا: التصميم التجريبي:ونظراً لتضمين هذا البحث متغيراً مستقلاً واحداً وهو

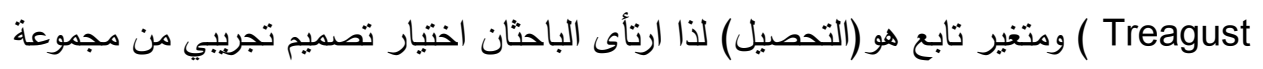

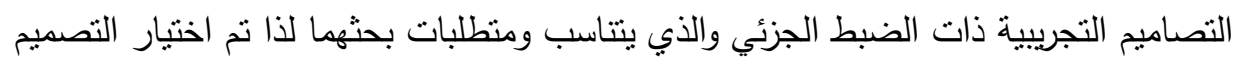

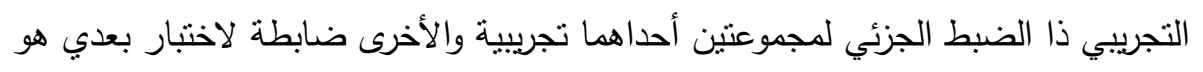
التحصيل.

ثانيـاً: مجتمـع البحث وعيتتها:تم تحديد مجتمع البحث بتلامذة الصف الخامس الابتدائي في

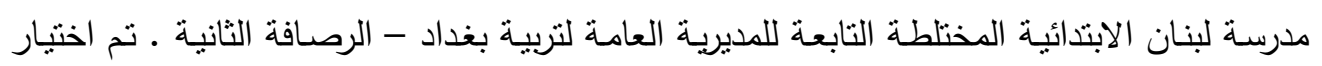

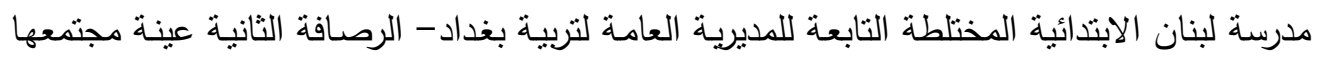

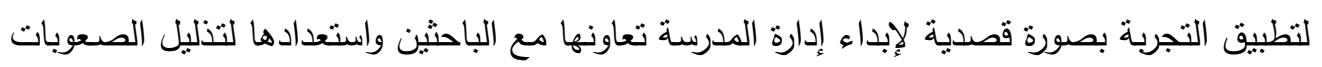

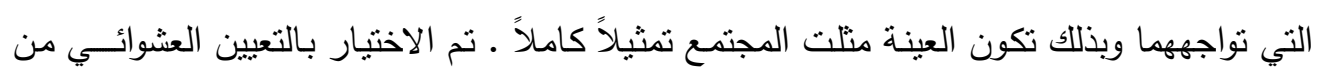

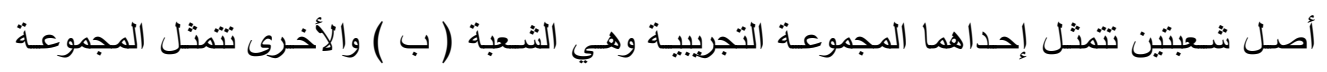

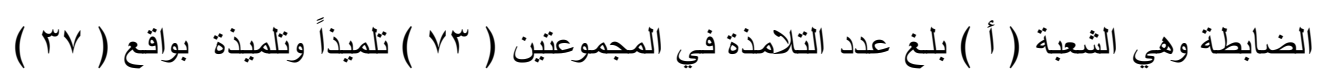

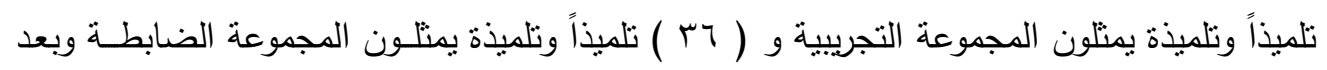

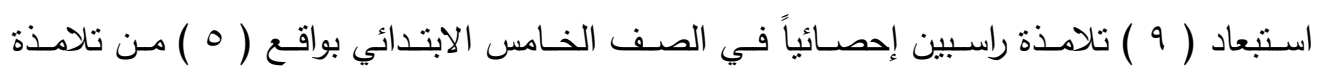

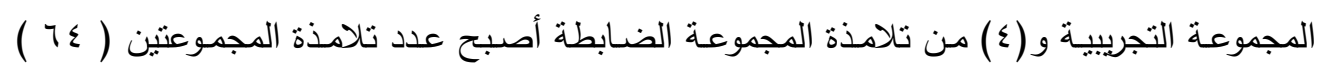

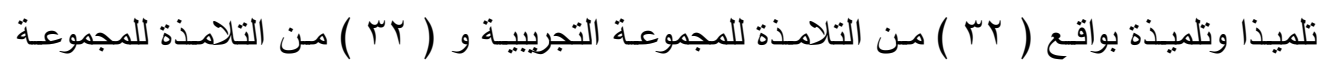

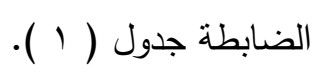




\section{العــــــد الثاني والعشرون}

\section{مجلـــة كليـــة التربيـــة}

\section{جدول ( ) ( )}

عدد التلامذة في المجموعتين التجريبية والضابطة قبل الاستبعاد الاحصائي ويعده

\begin{tabular}{|c|c|c|c|c|}
\hline عدد التلامذة بعد & عدد التلامذة & عدد التلامذة قبل & المجموعة & الثعبة \\
\hline r & 0 & $r v$ & التجريبية & ب \\
\hline r & $\varepsilon$ & ro & الضابطة & أ \\
\hline $7 \varepsilon$ & 9 & $v r$ & المجموع & \\
\hline
\end{tabular}

ثالثاً: تكافؤ مجموعتي البحث:للتأكد من تكافؤ مجموعتي البحث التجرييية والضابطة أجرى الباحثان التكافؤ في بعض المتغيرات ذات العلاقة المباشرة في إجراء التجربة وهي:

1- الذكاء: قام الباحثان باختبار مقياس رافن الثلاتي وهو ( أ ، ب ، ج ) والتي شملت على (

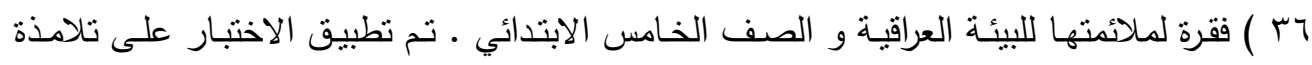

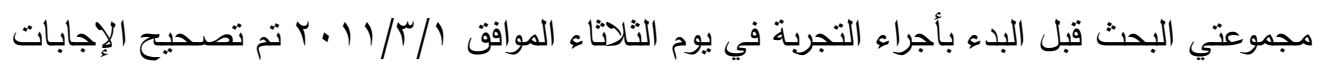

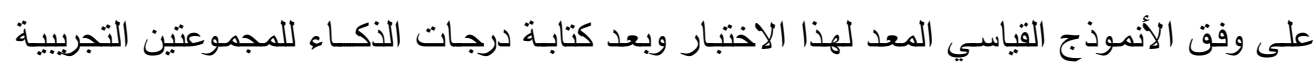

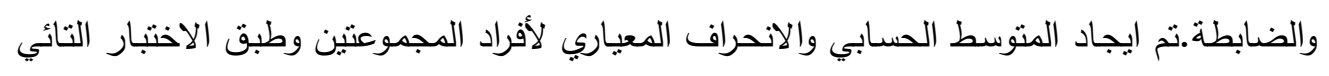

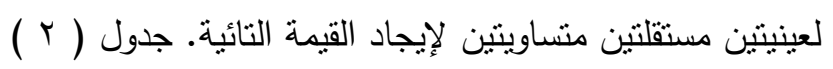


العـــــــد الثاني والعشرون

مجلــــة كليــــة التربيــــة

\section{جدول (r)}

المتوسط الحسابي والاتحراف المعياري والقيمة التائية المحسوية والجدولية للمجموعتين التجريبية والضابطة في متغير الأكاء

\begin{tabular}{|c|c|c|c|c|c|c|}
\hline \multirow{2}{*}{ الاحلالة } & \multicolumn{2}{|c|}{ القيمة التائية } & \multirow{2}{*}{ الانحراف } & \multirow{2}{*}{ المتوسط } & \multirow{2}{*}{ عدد } & \multirow[t]{2}{*}{ المجموعة } \\
\hline & الجدولية & المحسوبة & & & & \\
\hline \multirow[b]{2}{*}{ غير دالة } & \multirow[b]{2}{*}{$r, \ldots$} & \multirow[b]{2}{*}{$\cdot, V Y T$} & $7, \leq \leqslant 9$ & r., V^I & r & التجريبية \\
\hline & & & $0,9 M V$ & Y I, 9.7 & r & الضنابطة \\
\hline
\end{tabular}

ان القيمـة التائيـة المحسوبة لتلامذة المجموعتين لمتغير الذكاء هي (TYY, • • ) وهي اقل من القيمـة الجدولية ( r ) عند مستوى دلالة ( 0.,. ) ) وبدرجة حرية ( r ( ) مما يدل على تكافؤ المجموعتين في هذا المتغير.

Y- التحصيل السابق في مادة العلوم:هو درجات تلامذة مجموعتي البحث التجريبية والضابطة في

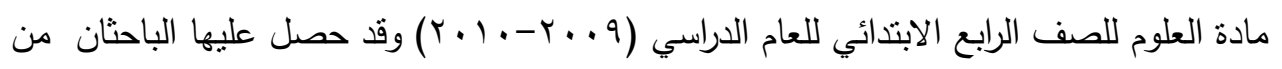
سجلات الدرجات لدى ادارة المدرسة .تم استخراج منتوسط درجات نلامذة المجموعة التجريبية والمجموعة الضابطة والانحراف المعياري والقيمة التائية باستعمال الاختبار التائي لعينتين مستقلتين متساويتين جدول ( م ) ) 
العــــــدد الثاني والعشرون

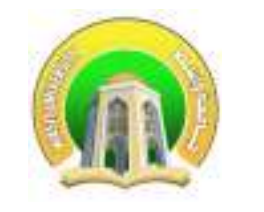

\section{مجلــــة كليــــة التربيــــة}

\section{جدول (r) ( ) (r)}

المتوسط الحسابي والانحراف المعياري والقيمة التائية المحسوية والجدولية للمجموعتين التجريبية والضابطة في متغير التحصيل السابق في مادة العلوم

\begin{tabular}{|c|c|c|c|c|c|c|}
\hline \multirow{2}{*}{ الاحلالة } & \multicolumn{2}{|c|}{ القيمة التائية } & \multirow{2}{*}{ الانحراف } & \multirow{2}{*}{ المتوسط } & \multirow{2}{*}{ عدد التلامذة } & \multirow[t]{2}{*}{ المجموعة } \\
\hline & الجدولية & المحسوبة & & & & \\
\hline \multirow[t]{2}{*}{ غير دالة } & \multirow[t]{2}{*}{$r, \ldots$} & \multirow[t]{2}{*}{ דואו } & $\cdot, 9 \vee$. & 9,707 & rr & التجربيية \\
\hline & & & ו & $q, r \leqslant r$ & זr & الضابطة \\
\hline
\end{tabular}

r- المعلومـات السـابقة:اعد الباحثان اختباراً تحصيلياً في المعلومات السابقة في مادة العلوم مكون من ( • r ) فقرة وهو من الاختبارات الموضوعية من نوع الاختيار من متعدد رباعية البدائل مستتدة على مادة العلوم للسنوات الدراسية السابقة ولأجل معرفة مدى علاقة الاختبار وصسلاحه وصدقه تم عرضه على مجموعة من الخبراء واجريت بعض التعديلات عليه مستمدة من آرائهم ومقترحاتهم وطبق

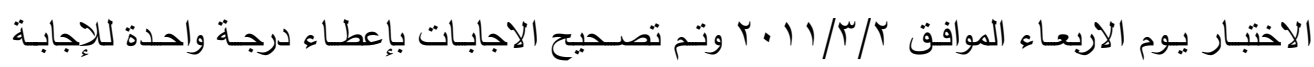

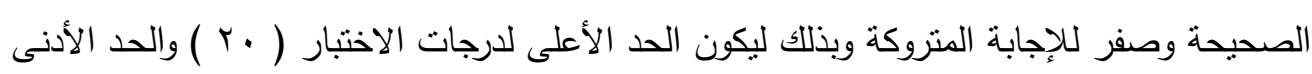
هو ( صفر ) • وتم استعمال الاختبار التائي لعينتين مستقلتين متساويتين جدول ( ع ع ) .

$$
\text { جدول ( ؛ ؛ ) }
$$

المتوسط الحسابي والانحراف المعياري والقيمة التائية المحسوية والجدولية للمجموعتين التجريبية والضابطة في متغير المعلومات السابقة

\begin{tabular}{|c|c|c|c|c|c|c|}
\hline \multirow{2}{*}{ الاحصائية } & \multicolumn{2}{|c|}{ القيمة التائية } & \multirow{2}{*}{ الانحراف } & \multirow{2}{*}{ المنوسط الحسابي } & \multirow{2}{*}{ عدد التالامذة } & \multirow[t]{2}{*}{ المجموعة } \\
\hline & الجدولية & المحسوبة & & & & \\
\hline \multirow[t]{2}{*}{ غير دالة } & \multirow[t]{2}{*}{$r, \ldots$} & \multirow[t]{2}{*}{ • • } & r,990 & $17,1 \wedge \mathrm{V}$ & rT & التجريبية \\
\hline & & & $r, \vee r q$ & $17,9 \cdot 7$ & r & الضـابطة \\
\hline
\end{tabular}

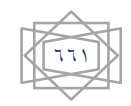


ع - العمـر الزمنـي:تم حسـاب عمر التلامذة بالأشـهر اذ تم الحصسول على البيانـات المتعلقة بهذا المتغير من البطاقة المدرسية لكل تلميذ وتلميذة من تلامذة عينة البحث ونم حساب المتوسط الحسابي والانحراف المعياري للعمر الزمني لتلامذة عينة البحث وباستعمال الاختبار التائي لعينتين مستقلتين

منساوينتين جدول(0)

\section{جدول (•)}

المتوسط الحسابي والانحراف المعياري والقيمة التائية المحسوية والجدولية للمجموعتين

التجريبية والضابطة في العمر الزمني

\begin{tabular}{|c|c|c|c|c|c|c|}
\hline \multirow{2}{*}{ الالالة } & \multicolumn{2}{|c|}{ القيمة التائية } & \multirow{2}{*}{ الانحراف } & \multirow{2}{*}{ المتوسط } & \multirow{2}{*}{ عدد } & \multirow[t]{2}{*}{ المجموعة } \\
\hline & الجدولية & المحسوبة & & & & \\
\hline \multirow{2}{*}{ غير دالة } & \multirow[t]{2}{*}{$r, \ldots$} & \multirow[t]{2}{*}{$\cdot, \wedge \leq \nearrow$} & T,TVT & $|r V, \cdot r|$ & r & التجريبية \\
\hline & & & $\varepsilon, \cdots$ & $\mid r V, \wedge \leq r$ & rT & الضابطة \\
\hline
\end{tabular}

ه- ضبط المتغيرات الدخيلة :حفاظاً على التصميم التجريبي تم ضبط المتغيرات الخارجية (الدخيلة ) التي قد تؤثز في نتائج التجربة (المتغيرين التابعين ) وهي :

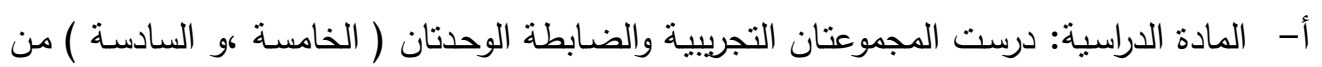

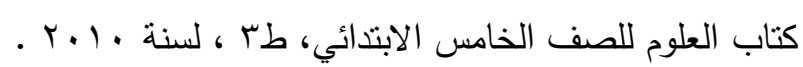
ب- مدة التدريس : بلغت مدة التدريس ( ^ أسـبيع ) اذ كان عدد الحصص ( rr ) حصة دراسية

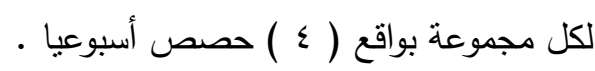
ج- توزيـع الحصـص : تـم تتظـيم الجدول الأسـبوعي بالتعـاون مـع إدارة المدرسـة بحيـث تـدرس

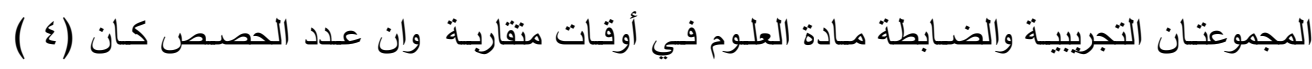
حصص لكل مجموعة أسبوعيا

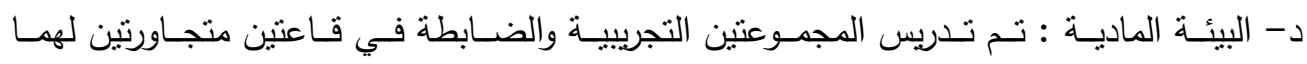
المواصفات نفسها تقريبا من حيث الإضـاءة وعدد المقاعد ونوع السبورة ( white board ) لأجل تنثيث اثر هذه المتغيرات النتائج 
ا- تحديد المـادة العلميـة: تم تحديد المادة العلمية التي تدرس في اثتاء التجربـة من كتاب مادة العلوم للصف الخامس الابتدائي، ط ب ،لسنة ، 1 . r ، وشملت ( الوحدنان الخامسة والسادسة ).

r- صـوغ الاغـراض السـلوكية وتحديـ مسـتوياتها : تم صباغة ( 77r ) غرضـا سلوكيا لمحتوى

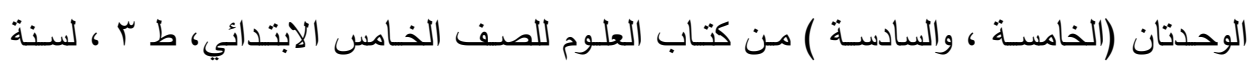

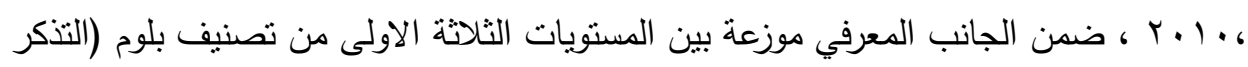
، و الاستيعاب ، و التطبيق ) ولمزيد من الدقة في تحري صباغتها وعلاقتها بالمحتوى المراد تدريسه فقد عرضت هذه الاغراض السلوكية على مجموعة من الخبراء والمتخصصين في التربية وطرائق التدريس والقياس والتقويم التربوي لبيان رايهم في سـامتها لتلك المستويات في ضوء فئه الملاحظات والتعديلات، صبغت بصورتها النهائية ملحق (1) (1) ل

ץ- إعداد الخطط التدريسية اعد الباحثنان (T ) خطة تدريسية وفقا لأنموذج تراجيست للمجموعة التجريبيـة ومثلها للمجموعـة الضـابطة وفقا للطريقة الاعتياديـة وبعد عرض نمـاذج من الخطط التدريسية على مجموعة من الخبراء والمتخصصين في هذا المجال تم صوغ الخطط بالصيغة

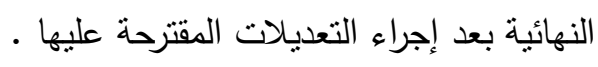

خامساً: بناء أداة البحث (الاختبار ألتحصيلي): اتبع الباحثان الخطوات الآتية لبناء الاختبار التحصيلي :

أ- - إعداد الفقرات : اعد الباحثنان اختباراً تحصيليا معتمدة على محتوى المادة الدراسية والإغراض السلوكية التي حددت بالنشاور مـع بعض معلمو مادة العلوم للصف الخامس الابتدائي فضـالًا عن اخذ أراء الخبراء والمتخصصين.

ب- إعداد الخارطة الاختياريـة (جدول مواصفات):وضـع الباحثان الخريطة الاختبارية اعتمادا على عدد الإغراض السلوكية ونوعها ونوعية مستوياتها ووجدت نسبة الإغراض السلوكية لكل وحدة

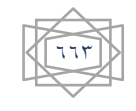


دراسية ولكل مستوى من مستويات بلوم الثلاثة الأولى( التذكر ، و الاستيعاب ، و التطبيق )

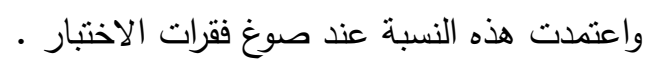

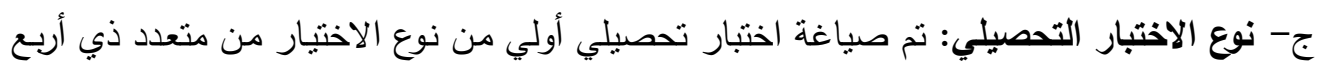

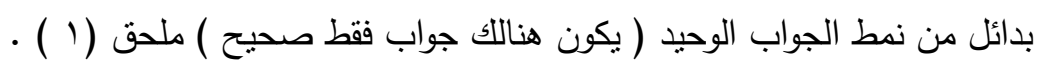

د- وضع تعليمات الاختبار : تم وضع تعليمات خاصة بالتلامذة توضح كيفية الاجابة عن اسئلة

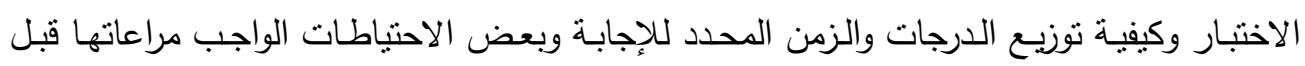
الاجابة.

\section{و -صدق الاختبار : نم التحقق من صدق الاختبار بإيجاد نوعين من الصدق :}

1- الصدق الظاهري : هو حكم المختص على درجة قياس الاختبار للسمة المقاسة، ويكون الاختبار

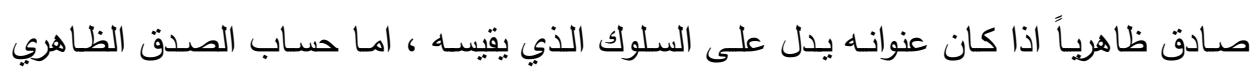

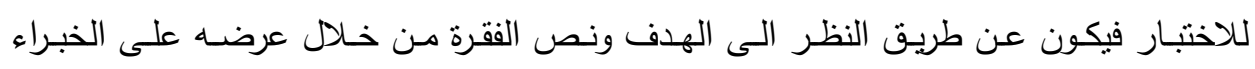

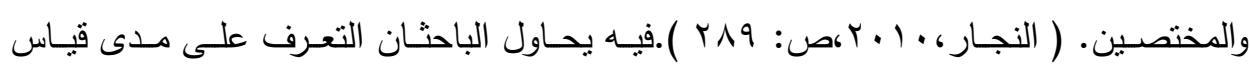

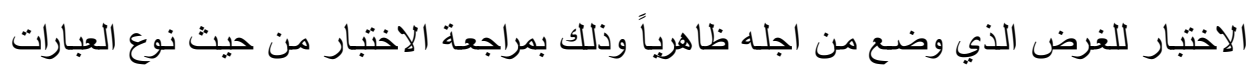

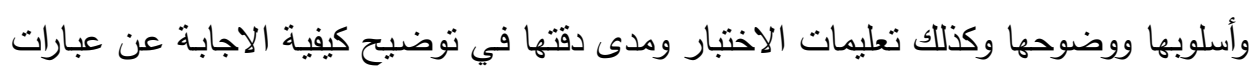

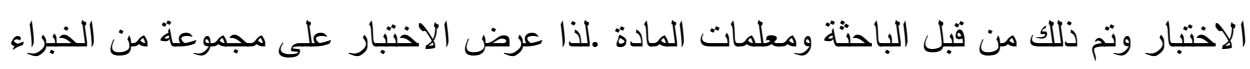

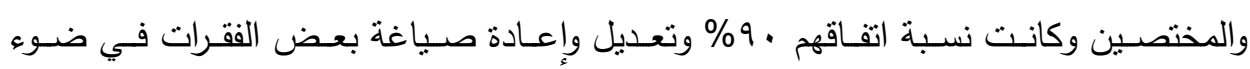
ملاحظاتهم.

r- صدق المحتوى:هو عمل إجرائي عقلاني او منطقي يقوم على ضرب من المزاوجة بين المادة

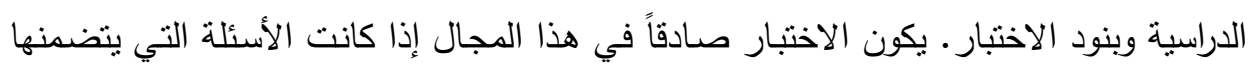

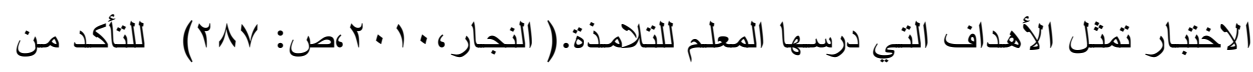
صدق المحتوى اعتمد الباحثان جدول المواصفات ليحقق ذلك ولبيان مدى ارتباط الفقرة بمستوى لاهن

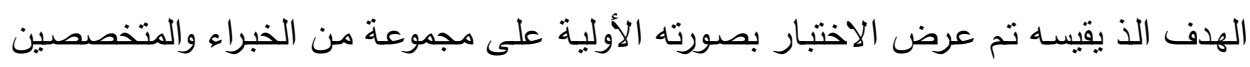

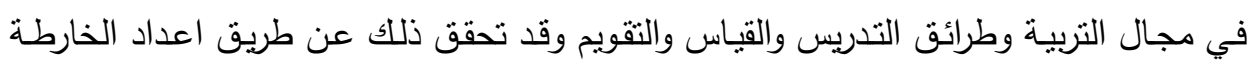

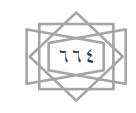




\section{العــــــد الثاني والعشرون}

\section{(1) \\ مجلـــة كليـــة التربيـــة}

الاختياريـة ( جدول المواصفات ). وفي ضوء الإجراءات السـابقة أصبح الاختبـار التحصبلي جاهزاً للنطبيق.

ز - صلاحية الاختبار : من اجل معرفة الفقرات الغامضة في الاختبار ووضوح تعليماته وكذلك الكان

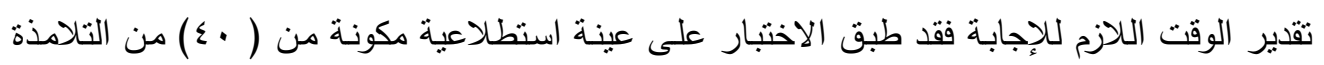

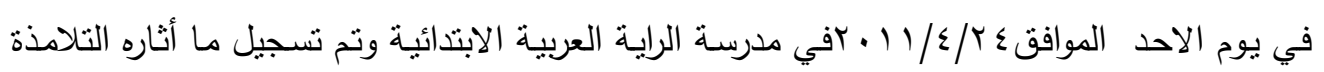

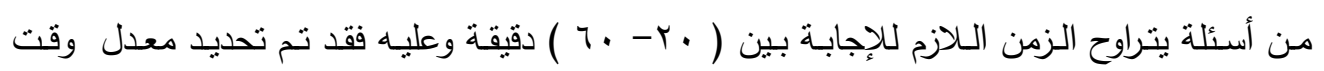
الاجابة على الاختبار التحصيلي( •ـ لدقيقة.

ح- الخصائص السيكو مترية للاختبار التحصيلي :

لأجـل التحقـق مـن الخصـائص السـيكومترية لفقـرات الاختبــار التحصـيلي طبـق على عينــة اسنطلاعية ثانية مكونة من ( . . . تلميذا وتلميذة في كل من المدارس الابتدائية الاتية (الراية

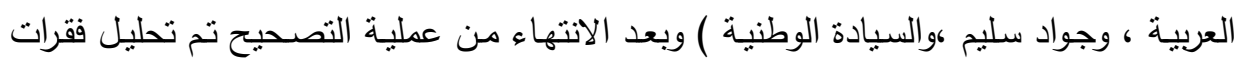

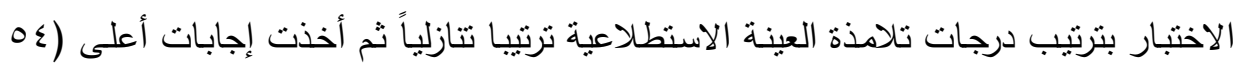

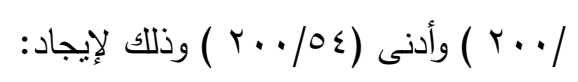

ا - معامـل سـهولة الفقـرة : إذ تم حسـاب معامل الصـعوبة باستعمال معامل الصـعوبة للفقرات

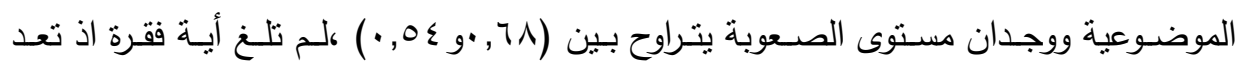

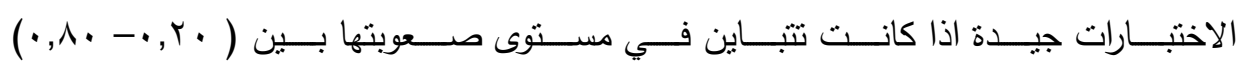

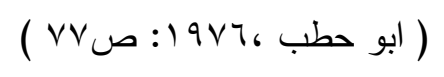

ץ- معامـل تمييز الفقرات : تم حساب معامل التمييز لكل فقرة باستعمال معادلة التمييز للفقرات

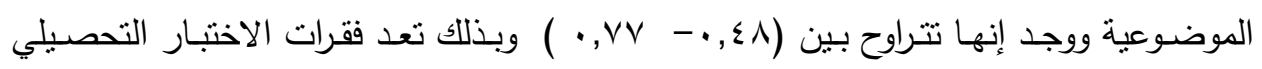

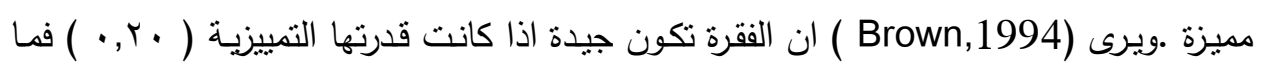

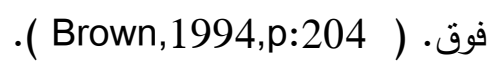


ب- قيـاس فعاليـة البـائل : لآجل حسـاب فعاليـة البدائل لققرات الاختبار تم تطبيق معادلة فعاليـة البدائل ووجد إنها نتراوح بين ( - ع ا , • و -9 r, • ) من الواضح إن جميع القيم سالبة وهذا يعني إن البدائل الخاطئة قد جذبت إليها عدداً من تلامذة المجموعة الدنيا أكبر من تلامذة المجموعة

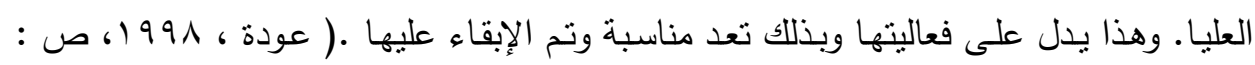

ع- الثبات : هو درجة التوافق أو التجانس بين مقياسين لثيء واحد ـ ( الزبيدي وماهر ، ب ... r، ص : 0بr) تم حساب الثبات للفقرات الموضوعية باستعمال كل من :

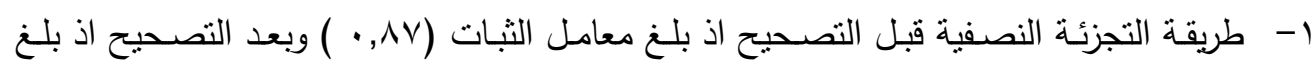

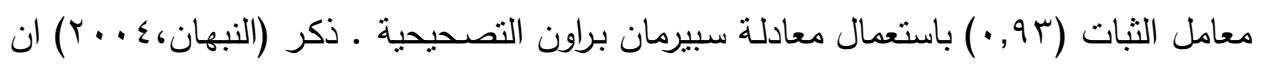

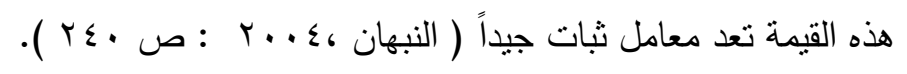
r- طريقة الفا كرونباخ اذ بلغ معامل الثبات (19, • ) .

خ - التحليـل الاحصـائي لفقـرات الاختبـار : وبعد التأكد من وضـوح فقرات وتعليمـات الاختبار ونتخيص الفقرات الغامضة وتوضيحها طبق الاختبار على عينة استطلاعية ثانية مكونة من

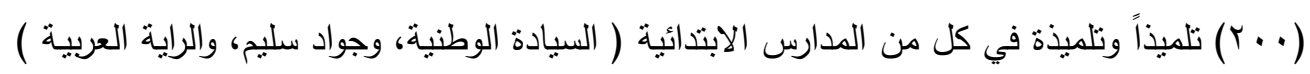
بعد الاتفاق مع إدارات المدارس على موعد الاختبار على النحو الآتي :

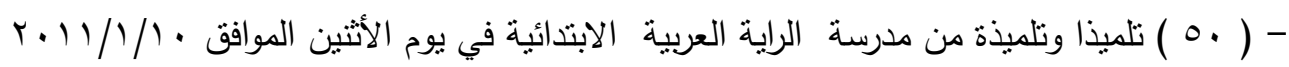

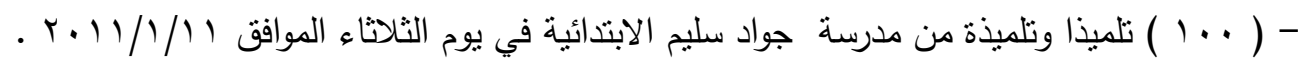

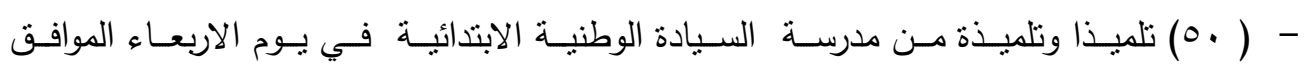
$r \cdot 11 / 1 / 1 r$

لغرض التحقق من الخصائص السايكو مترية لفقرات الاختبار صححت الفقرات الموضوعية بإعطاء

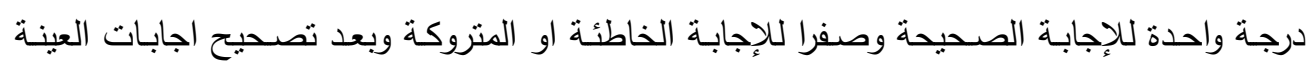
الاستطلاعية الثانيـة لفقرات الاختبـار تم ايجـاد تحليـل الفقرات بترتيب درجـات تلامذة العينـة ترتيبـاً

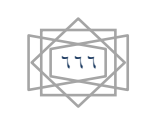




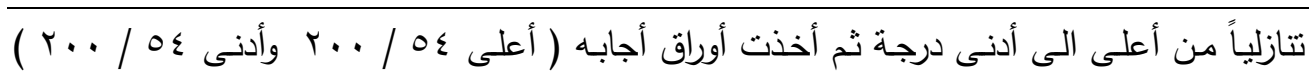
وذلك لإيجاد ما يأتي :

1- معامل سهولة الفقرة : هو مجموعة نسبة التلامذة في المجموعتين العليا والدنيا الذين أجابوا على

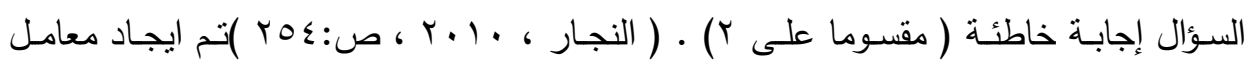
صعوبة الفقرات بعد حساب عدد الاجابات الخاطئة عن كل فقرة وطبق قانون صعوبة الفقرة

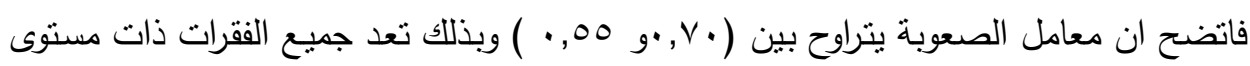

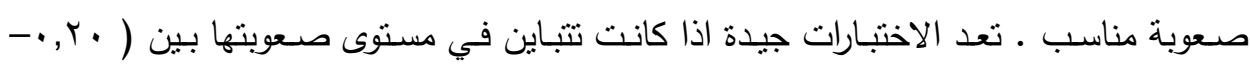

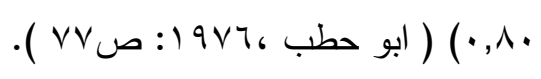

ץ- معامل تمييز الفقرة : هو قدرة السؤال على التمييز بين الافراد ـ أي قدرته على التمييز ما بين التلميذ الممتاز والجيد والمقبول والضعيف. وهو دليل على ان السؤال صـادقا فيما يقيسـه بدليل

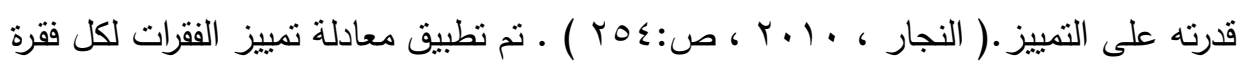

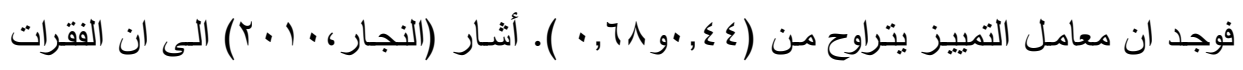

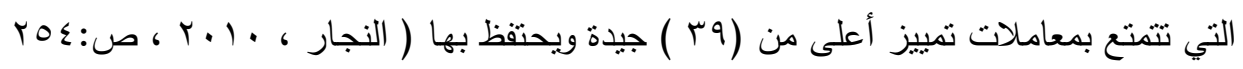
) · لذلك تعد فقرات الاختبار مقبولة من حيث قدرتها التمبيزية ولا تحذف منها أية فقرة .

ب- قيـاس فعاليـة البــائل : تشـير فعاليـة البـدائل : الـى قدرة بـدائل السـؤال ( خاصـة الأسـئلة الموضوعية من نوع الاختيار من متعدد ) على اجتذاب استجابات من المفحوصين.( النجار ،

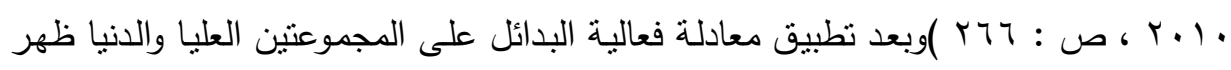

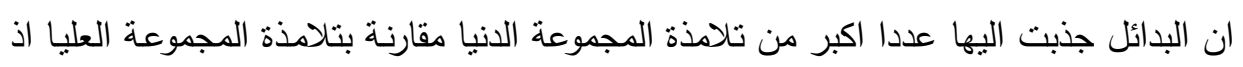

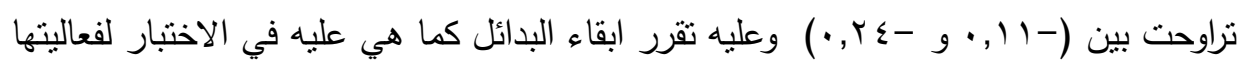
في جذب التلامذة .

ط- ثبات الاختبار : يشير الثبات الى درجة الاستقرار او الاتساق في الدرجات المتحققة على أداة القياس فالاختبـار الذي تتمتع الدرجات عليـه بالثبات هو الاختبـار الذي تكون الدرجات عليه

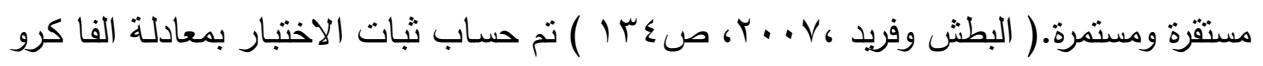




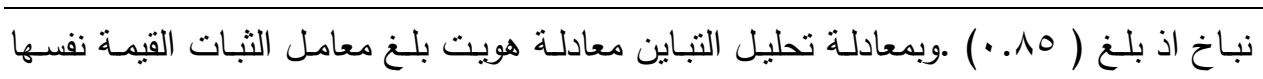

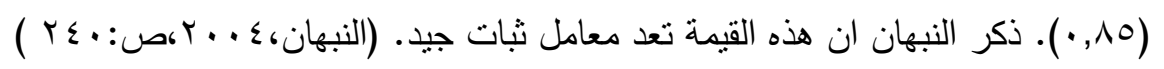

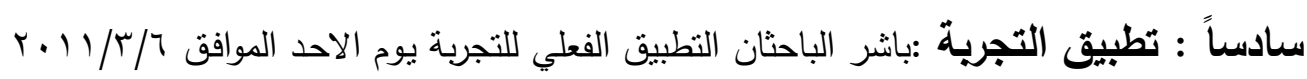

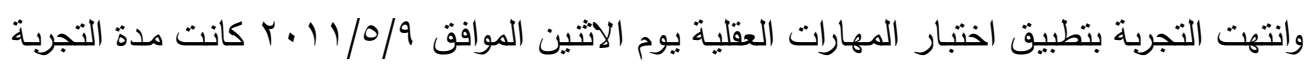

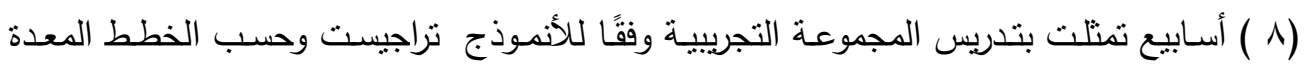

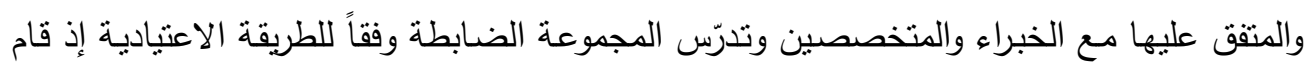

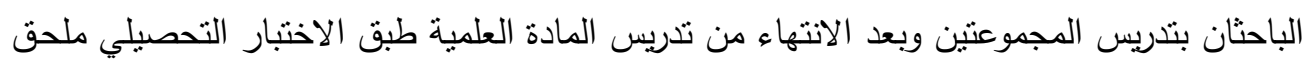

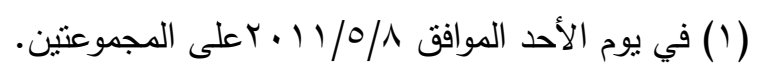

سـابعاً : الوسـائل الإحصـائية:تم استعمال الحقيبة الإحصائية spss اذ اعتمد الباحثان وسائل

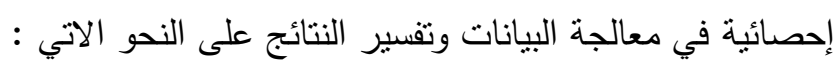

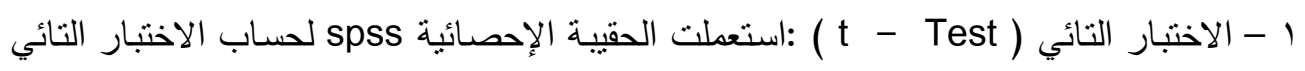

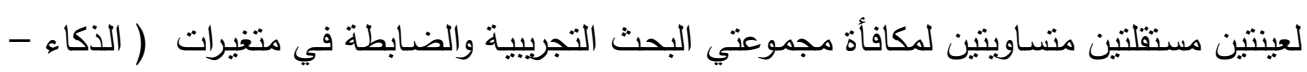

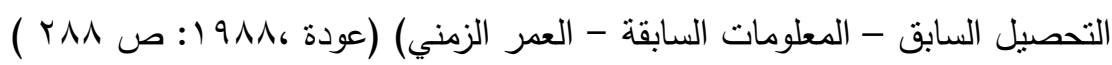

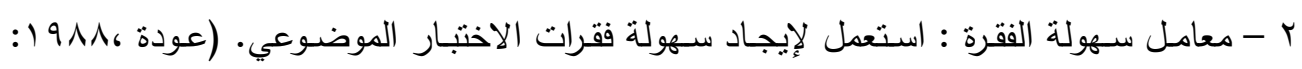
( I

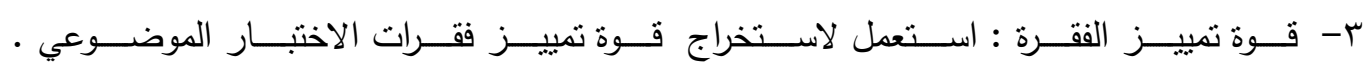

$$
\text { ( })
$$

ع-معادلة فعالية البدائل:استعملت لإيجاد معامل فعالية البدائل الخاطئة للاختبار الموضوعي .

$$
\text { ( })
$$

ه-معادلة سبيرمان براون التصحيحية:استعصلت الحقيبة الإحصائية spss لحساب ثبات الاختبار

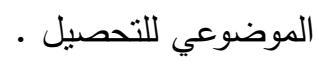




\section{العــــــد الثاني والعشرون}

\section{(I)}

\section{الفصل الرابع}

يتضمن هذا الفصل عرضا للنتائج التي تم التوصل اليها ثم تفسيرها ومناقثتها وكالاتي:

أولا: عرض النتائج :لغرض التحقق من هدف البحث عن طريق اختبار صحة الفرضية الصفرية اتبع

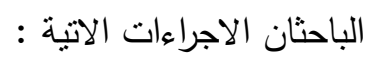

تم ايجـاد المتوسـ الحسـابي والتبـاين للـدرجات الخـام لتلامـذة كل مـن المجمـوعنين التجريبيـة

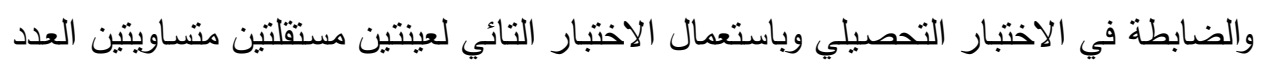

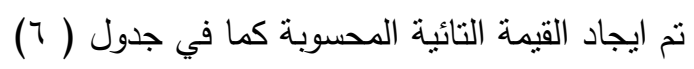

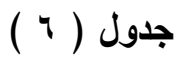

المتوسط الحسابي والانحراف المعياري والقيمة التائية المحسوية والجدولية لارجات

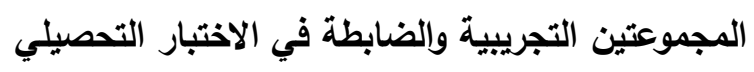

\begin{tabular}{|c|c|c|c|c|c|c|}
\hline \multirow{2}{*}{ الاحصائية } & \multicolumn{2}{|c|}{ القيمة التائية } & \multirow{2}{*}{ معياري } & \multirow{2}{*}{ الحتوسط } & \multirow{2}{*}{ عدد التلامذة } & \multirow[t]{2}{*}{ المجموعة } \\
\hline & الجدولية & المحسوبة & & & & \\
\hline \multirow[t]{2}{*}{ دالة } & \multirow[t]{2}{*}{$r, \ldots$} & \multirow[t]{2}{*}{$r, T r}$. & $\varepsilon$, TO & $Y_{0, \varepsilon \cdot T}$ & r & التجريبية \\
\hline & & & $0, \cdot V r$ & rr, ro. & r & الضابطة \\
\hline
\end{tabular}

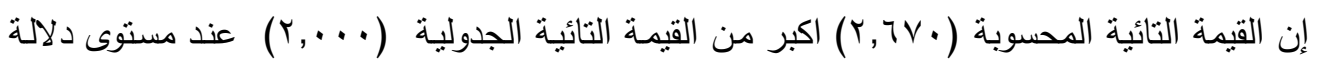

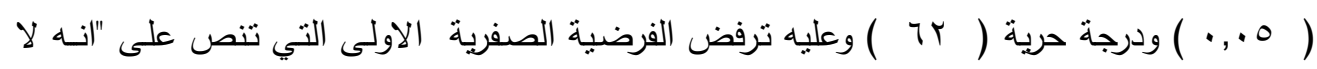

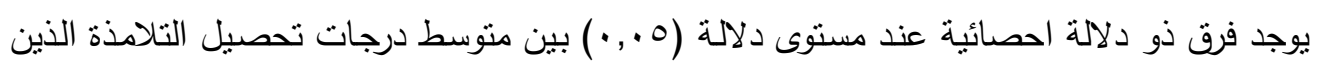

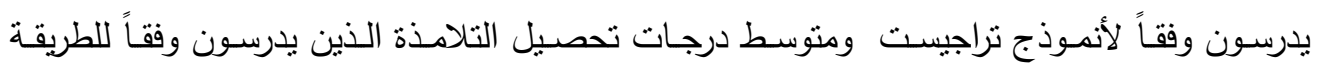

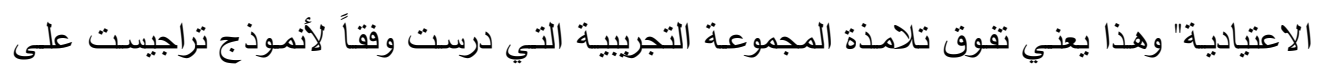

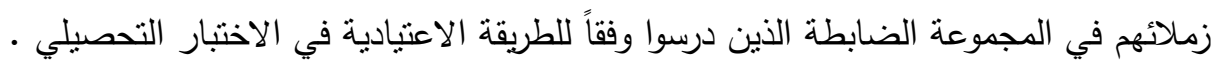

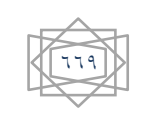


ثانياً: تفسير النتائج :اظهرت النتائج المتعلقة بالفرضية الصفرية في جدول ( ج) إن المجموعة التي درست وفقاً لأنموذج تراجيست تفوقت في اختبار التحصيل على المجموعة الضابطة التي درست وفقاً للطريقة الاعتيادية مما يدل على ان هذا الأنموذج له اثر ايجابي في تحصيل التلاميذ ويعزى ذلك

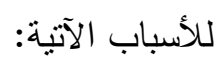

ا- ان طبيعـة عرض المـادة التعليميـة عن طريق أنموذج تراجيست للتدريس بالتشبيهات قد جعل عملية التعليم محبية لدى التلامذة لان التشبيهات تعمل على ربط التلامذة بحياتهم اليومية .

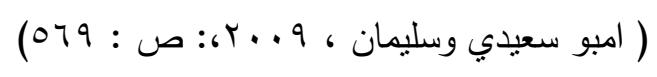

r- قد وفر فرصة للتفاعل النشط بين التلامذة وعناصر البيئة .وقد وفر مناخ صفي ديمقراطي دافئ يشع بالمحبة والحرية .

ץ- قد شـجع التلامذذة على التعامـل الحر مـع الافكار والاشـياء.( قطـامي 99191، ص: 17 (1(1) 74

ع- إن التعلم في المدرسة الابتدائية يمكن أن يكون أكثر متعة وبهجة إذا وجدت المشكلات والمسائل المستتبطة من حولهم كما انها نثير فضولهم اذا تمحور تعليم العلوم حول هذه المسائل مسثقصيا

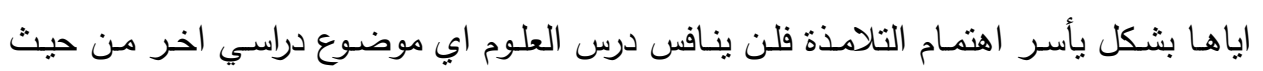

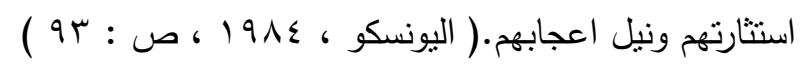

$$
\begin{aligned}
& \text { واتفقت نتائج البحث مع نتائج دراسة ( Kleaner,1991 ) ودراسة( الاغا ،V. . . Y). } \\
& \text { ثالثاً: الاستنتاجات : في ضوء نتائج البحث يستتتج الباحثان الأتي : }
\end{aligned}
$$

-اعتماد انموذج تراجيست في تدريس مادة العلوم للصف الخامس الابتدائي له اثر في رفع تحصبلهم

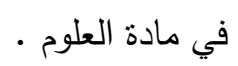


رابعاً: التوصيات : في ضوء نتائج البحث يوصي الباحثان بما يأتي:

1- اعتماد أنموذج تراجيست في ندريس مادة العلوم لأثره الواضح في رفع مستوى التحصيل للتلامذة

r- التتسيق المباشر مع دائرة المناهج العامة وتزويدهم بأحدث البحوث ليطوروا بها المواد الدراسية

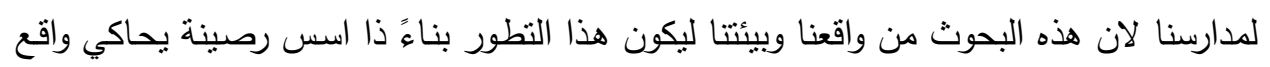
التزبية والتعليم في مجتمعنا.

r- إدخال إنموذج تراجيست ضمن مفردات طرائق التدريس في كليات التربية ومعاهد إعداد المعلمين

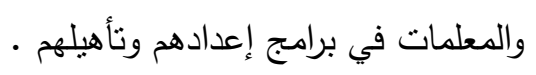

خامساً: المقترحات : في ضوء نتائج البحث يقترح الباحثان اجراء الدراسات الاتية: ا - أثر أنموذج نراجيست في الترريس لمراحل دراسية أخرى ولمواد دراسية مختلفة وفي متغيرات تابعة

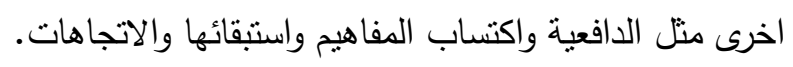
r- دراسة مقارنة بين إنموذج تراجيست ونماذج تدريسية أخرى. 


\section{العـــــــد الثاني والعشرون \\ مجلــــة كليــــة التربيــــة

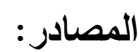 \\ اولًا: المصادر العربية: \\ "أقران الكربيم.}

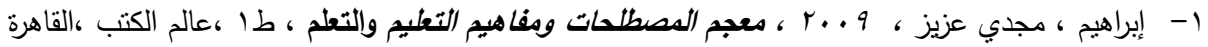

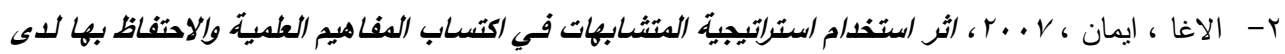

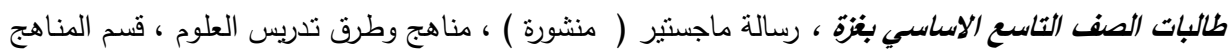
، الجامعة الاسلامية بغزة ، كلية التربية.

r- ابو حطب ، فؤاد عبد اللطيف، وسيد احمد عثمان، 19V7 ، التزانه ، التقويم النفسي ، مكتبة الانجلو المصرية ،القاهرة.

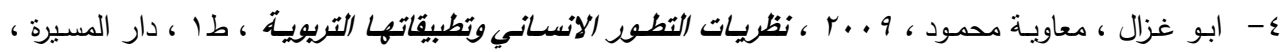

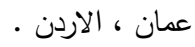

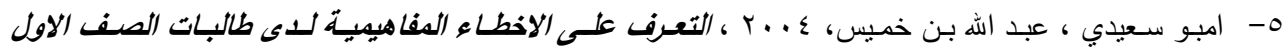
الثانوي ببحافظة مسقط في مادة الاحياء باستغدام شبكة التواصل البنائية ، مجلة مركز البحوث التربوية -

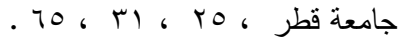

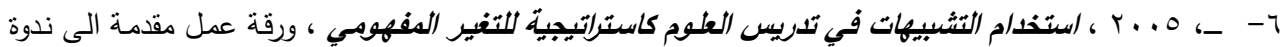

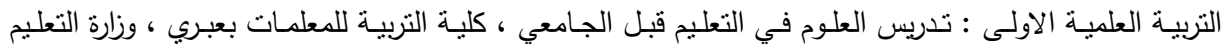
العالي

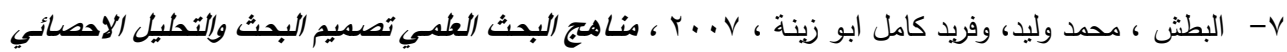
، طا ، دار المسيرة للنشر ، عمان.

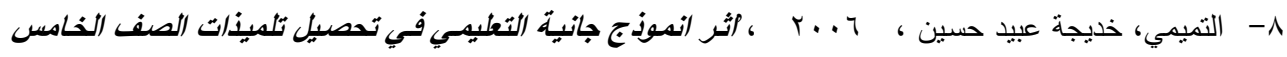

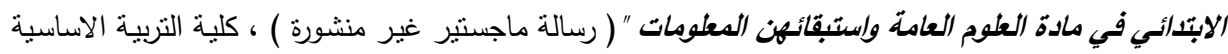

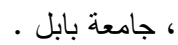

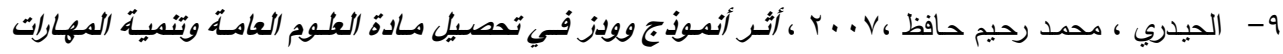
العقلية لاى طلاب الصف الاول المتوسط، ، كلية التربية / ابن الهيثم - جامعة بغداد ، بغداد.

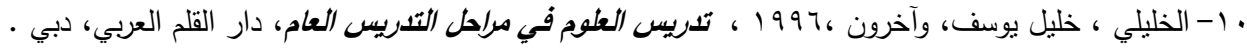

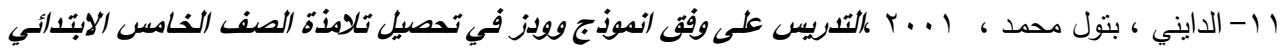
في مادة العلوم " ، ( رسالة ماجستير غير منشورة ) ، جامعة بغداد، كلية التربية ابن الهيثم ، بغداد.

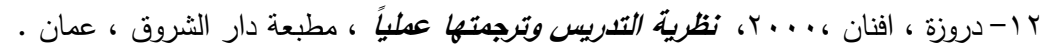

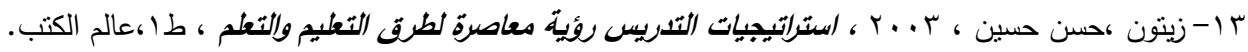

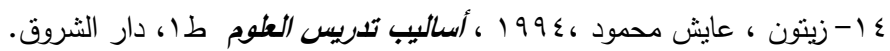

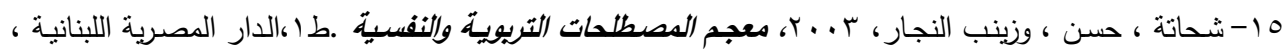




\section{العـــــــد الثاني والعشرون}

\section{مجلــــة كليــــة التربيــــة}

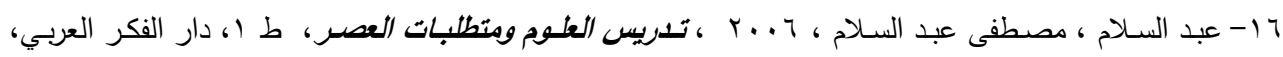

القاهرة .

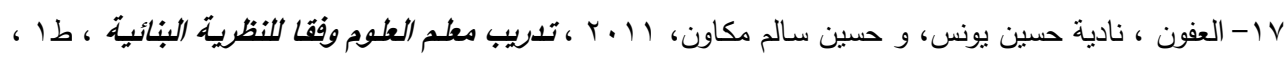

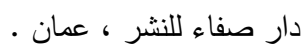

1 - العكيلي ، احمد عبد الزهرة ، 99 19، اثر استخدام انمونجي ميرل - تبنسون وجانيه التعليميين في اكتساب

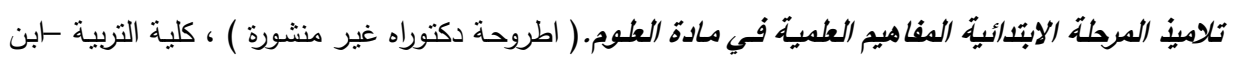

$$
\text { الهيثم ، جامعة بغداد ، بغداد. }
$$

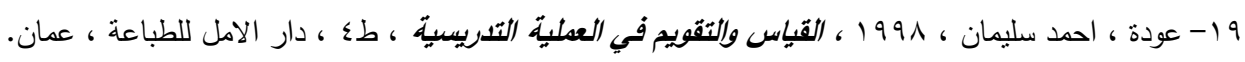

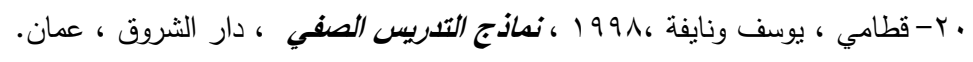

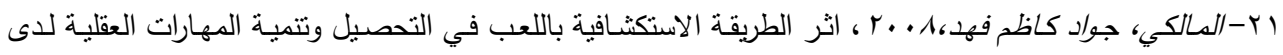

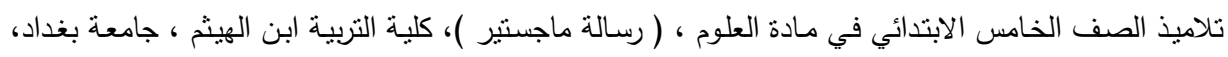

$$
\text { بغداد . تلامبذ. }
$$

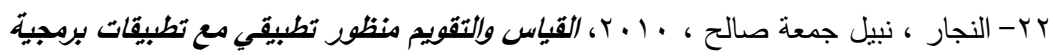

$$
\text { Spss }
$$

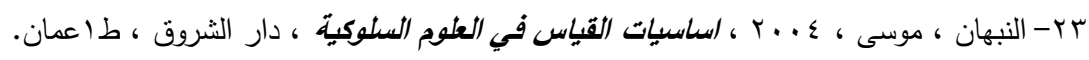

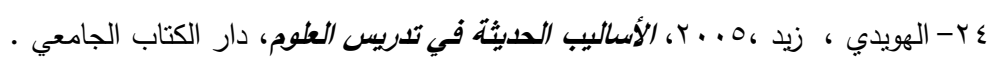

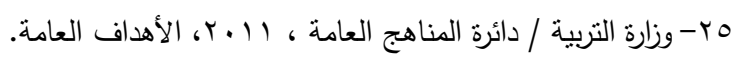

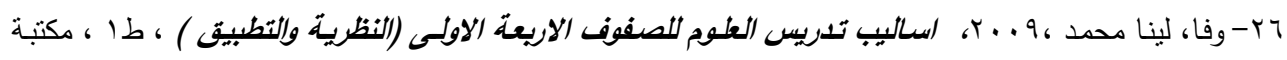

$$
\text { المجتمع العربي ، عمان. }
$$

VY اليونسكو ، ع 19 1 ، التريبية العلمية والتكنلوجية في التنمية الوطنية ، صف دار الفجر للطباعة مطبعة تيبو

$$
\text { برس ، بيروت. }
$$

\section{ثانيا : المصادر الأجنبية:}

28- Brown de(1994 : explamatory facilitaing conceptual change vising_Analogies and model Journal.sci.educ. vol.16.no.2.pp(201-214).

29- Kliener,c.s(1991):the effect of synceties tranind on student creativity and achievement in science, dissertion abvstract intr national,vol.:48, no.6.

30- O,Brien, Geoffrey William ,2002: The Development and Implementation of a Multimedia Program that Uses Analogies in Senior High School Chemistry to Enhance Student Learning of Chemical Equilibrium .presented Doctor of Science Education of the Curtin University of Technology.

rr-Teragust , D.F(1992):Science Teachers Using Of Analogies Observation Froms

Classroom Practice, International Journal Of Science Education, Vol.1,No,4 


\section{ملحق (1)}

\section{الاختبار ألتحصيلي لمادة العلوم للصف الخامس الابتدائي}

$$
\begin{aligned}
& \text { الاسم: } \\
& \text { عزيزي التلميذ................. عزيزتي التلميذة... }
\end{aligned}
$$

بين يديك اختبار يتضمن أسئلة تكون إجابتك عليها بوضع دائرة حول الحرف الذي يشير إلى الإجابة الصحيحة ولديك

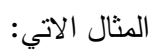

$$
\text { - ت العنبر الإسكارس من مجموعة: }
$$

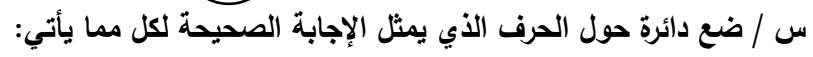

ا- تسمى القوى التي تعمل على تقريب اقطاب المغناطيس من بعضها بقوى:

ج. التجاذب

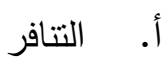

د. الثد

ب. ب. الربط

ץ- نستعمل المغناطيس الصناعي في الاغراض الصناعية ولا نستعمل الطبيعي بسبب كونه:

ج. لا يناسب الأغراض الصناعية

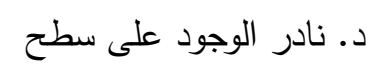

أ. ـقيل الوزن ويصعب نقله

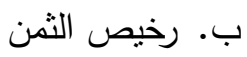

$$
\text { الأرض بل }
$$

r- من بين الاثياء التي لا يجذبها المغناطيس:

ع - تسمى لفات السلك الكهربائي حول المغناطيس بـ :

$$
\text { ب. أ. الدائرة الكهربائية }
$$

0- احد المصادر التي تزودنا بالكهرباء في المنزل هي:

ج. المولد الكهربائي

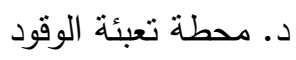

أ. البطارية الجافة

ب. البطارية السائلة

צ- نحدد اقطاب المغناطيس الصناعي عن طريق :

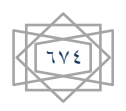




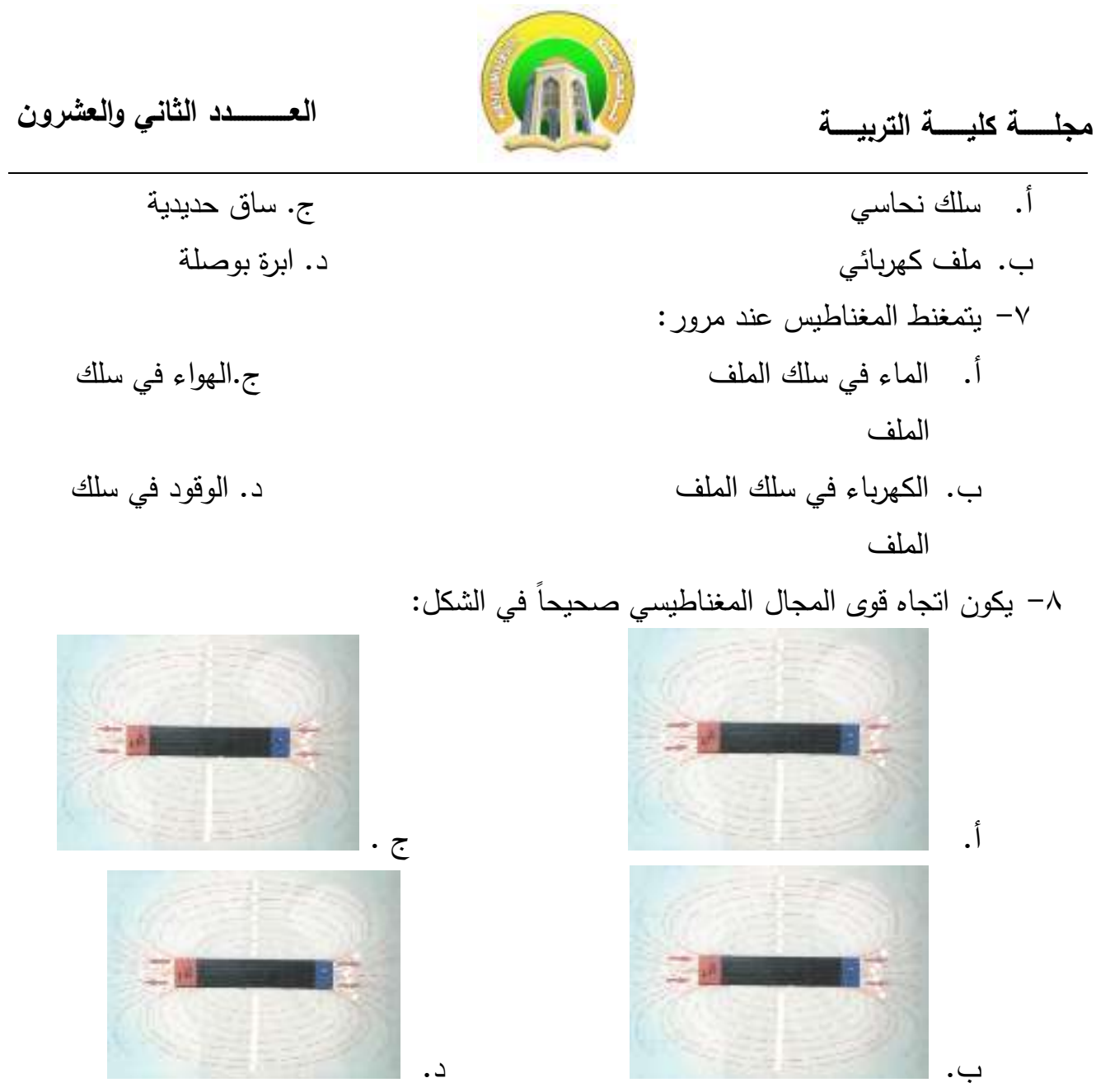

9- يسمى الجزء في الدائرة الكهربائية الذي يفتح ويغلق الدائرة الكهربائية:

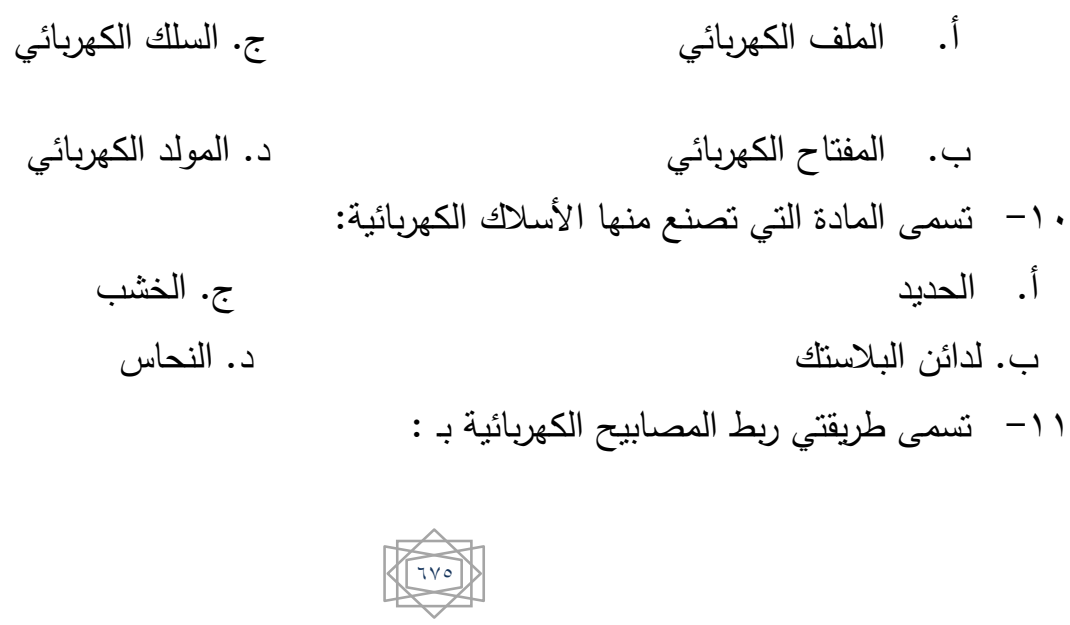




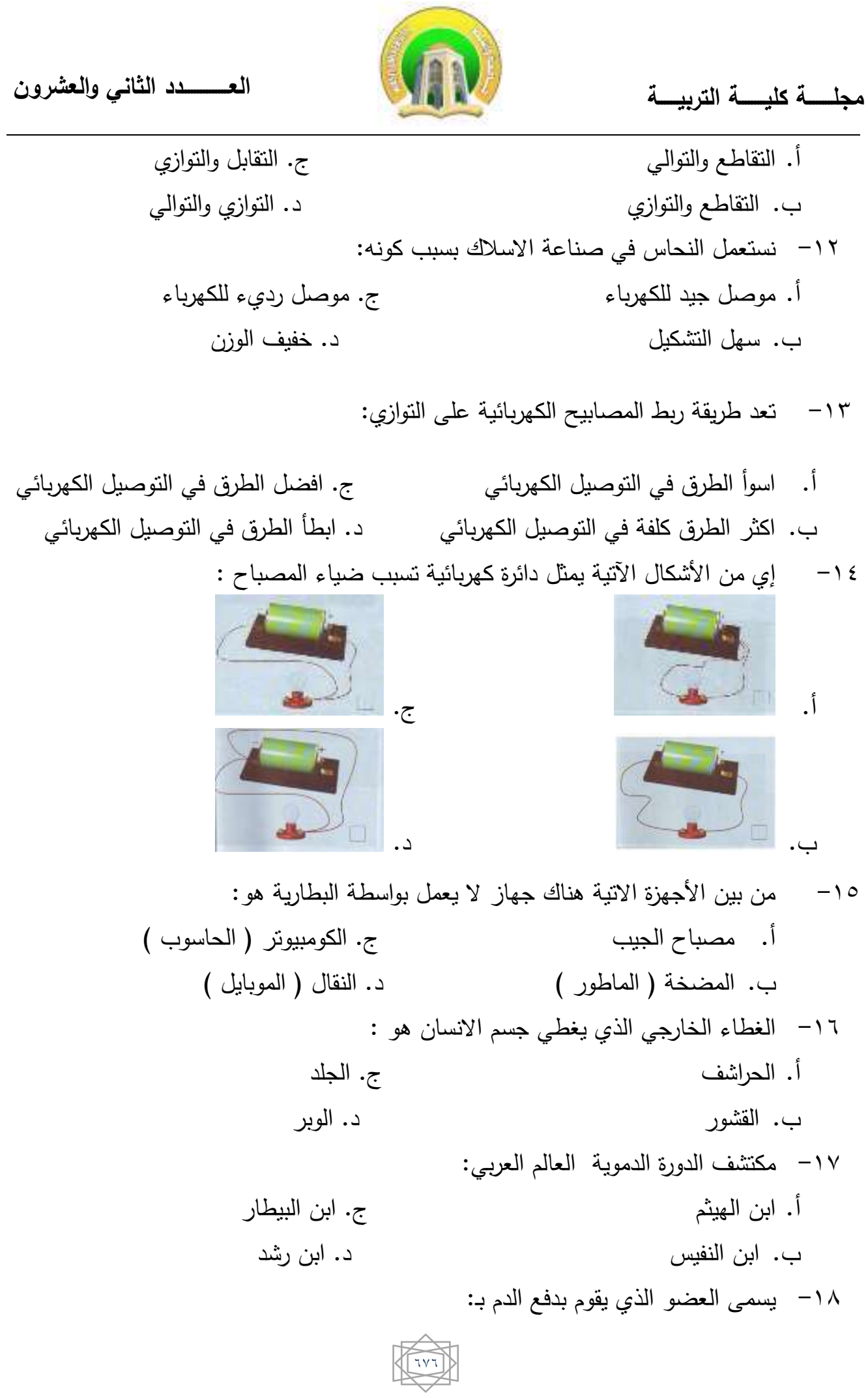




$$
\begin{aligned}
& \text { العــــــدد الثانـي والعشرون } \\
& \text { ج. المريء } \\
& \text { د. الكبد } \\
& \text { أ. الرئتين } \\
& \text { ب. ب. القلب } \\
& 9 \text { 19- العضلات هي قطع من: } \\
& \text { ج• الجلد }
\end{aligned}
$$

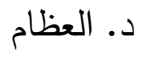

$$
\begin{aligned}
& \text { أ. اللحم } \\
& \text { ب. ب. الغضاريف } \\
& \text { • r- يعد جزء من مكونات الجهاز التتفسي: } \\
& \text { ج. الاثتي عشر } \\
& \text { د. القلب } \\
& \text { أ. القصبة الهوائية }
\end{aligned}
$$

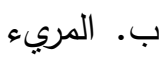

$$
\begin{aligned}
& \text { ا Y- بسمى الجزء الأول من الأمعاء الدقيقة بـ: }
\end{aligned}
$$

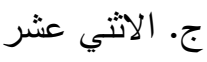

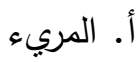

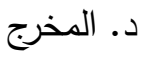

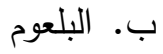

$$
\begin{aligned}
& \text { r }
\end{aligned}
$$

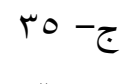

$$
\begin{aligned}
& \text { أ. } \\
& \text { נr }
\end{aligned}
$$

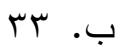

$$
\begin{aligned}
& \text { ج. امراض الجلد } \\
& \text { أ. تجفيف الجلد }
\end{aligned}
$$

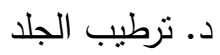

$$
\begin{aligned}
& \text { ب. تشقق الجلد } \\
& \text { ع r- تقوم الشعيرات الدموية المحيطة بجدار الامعاء بـ: } \\
& \text { ج. عصر الغذاء } \\
& \text { أ. طرح الغذاء المهضوم } \\
& \text { ب. امتصاص الغذاء المهضوم }
\end{aligned}
$$

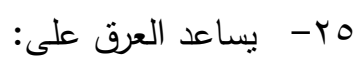

$$
\begin{aligned}
& \text { ج. تدفئة وتبريد الجسم } \\
& \text { أ. تبريد الجسم } \\
& \text { د. تهوية الجسم }
\end{aligned}
$$

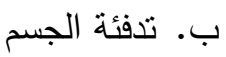

$$
\begin{aligned}
& \text { ج. عظمية تسهل حركتها } \\
& \text { أ. صبغية تسهل حركتها } \\
& \text { د. دهنية تسهل حركتها } \\
& \text { ب. ليفية تسهل حركتها }
\end{aligned}
$$

ج




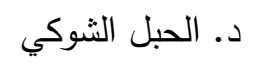

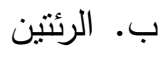

ت. من الامثلة البيئية التي نتبه وظيفة الهيكل العظمي للإنسان هو:

ج. الاسمنت في البناء

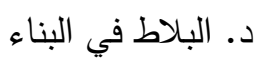
أ. قضبان الحديد في البناء

ب. الجص في البناء

ث. من الامتلة البيئية التي نتبه عمل القباء

ج. المضخة الكهربائية

د. الأقطاب المغناطيسية

$$
\text { أ. المفتاح الكهربائي }
$$

ب. الأسلاك الكهربائية

ج. من الامتلة البيئية التي تشبه عمل الجهاز هو عمل مجموعة من: ج. الجيوش المتقاتلة

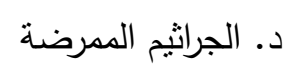

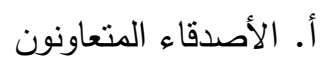

ب. الأقطاب المنتافرة

ح. يسمى العضو الذي يساعد الأنسان على النطق ب:

ج. المريء

أ. اللسان

د. اللثة

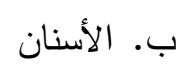

خ. ابهام الأنسان يساعده على:

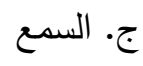

أ. أمسك المك المكن

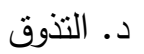

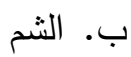

